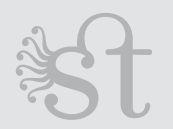

\title{
Carta de Galileu Galilei a Francesco Ingoli ${ }^{3}$
}

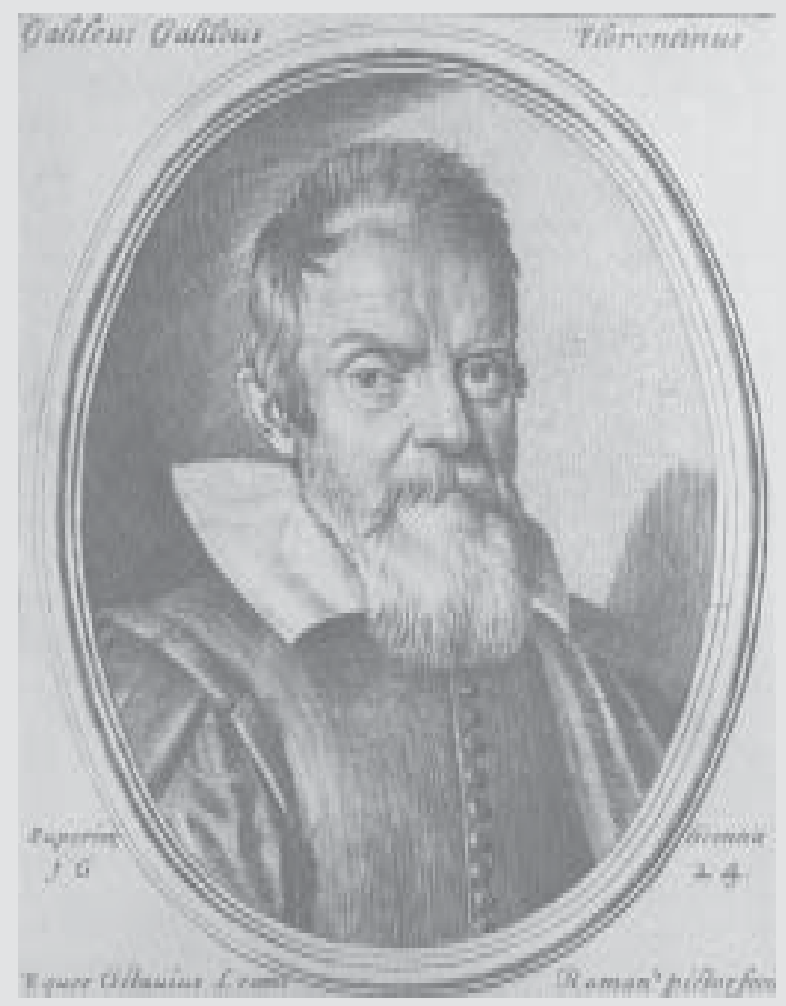

[509] Ao muito Ilustre e muito Excelente

Senhor Francesco Ingoli

de Ravena

Oito anos já se passaram, Senhor Ingoli, que eu, encontrando-me em Roma, recebi de vós um escrito, quase na forma de carta, endereçada a mim, na qual vos esforçáveis para demonstrar falsa a hipótese copernicana, em torno da qual muito se tumultuava naquele tempo; falsa digo, principalmente quanto ao lugar e ao movimento do Sol e da Terra, sustentando vós estar esta no centro do universo e ser totalmente imóvel e aquele móvel e tão afastado do referido centro quanto da própria Terra; para sua confirmação produzíeis três gêneros de argumentos, os primeiros astronômicos, 
os segundos filosóficos, os terceiros teológicos. Depois, muito cortesmente solicitáveis que eu vos devesse responder, quando eu tivesse percebido alguma falácia ou outra razão menos concludente. Eu, movido por vossa ingenuidade e por outros afetos corteses percebidos em vós de outros tempos passados e seguríssimo de que longe de toda inveja e com ânimo sincero me havíeis ofertado os vossos pensamentos, depois de têlos uma e duas vezes considerados, desejoso de retribuir, do melhor modo que me fosse possível, a sinceridade de vosso ânimo, concluí comigo mesmo nenhum outro meio ser mais oportuno para efetuar tal desejo que o silêncio; parecendo-me que desse modo eu não acabaria por amargar o gosto que quero crer que vós sentistes ao persuadir-vos de ter convencido um tal homem, [510] como é Copérnico, e que ao mesmo tempo eu deixava, naquilo que dependia de mim, inteira a vossa reputação junto àqueles que tivessem lido vosso escrito. Não direi que a estima de vossa fama me fizesse desprezar a minha própria, a qual jamais acrediteis que devesse ser tão tênue, que pudesse acontecer o caso em que alguém, que bem tivesse examinado as vossas contradições àquela opinião que eu então reputava como verdadeira, tivesse de meu silêncio que inferir em mim uma inteligência menor que aquela que bastava para refutá-las a todas; todas, digo, excluídas as teológicas, acerca das quais me parece que se deve proceder bastante diferentemente que acerca das outras, pois são daquelas que não estão sujeitas às refutações, mas somente são capazes de interpretações. Entretanto, tendo ultimamente retornado a Roma, para cumprir aquela obrigação aos santíssimos pés do Sumo Pontífice Urbano vııı, ao qual me mantêm ligado a antiga obrigação e os múltiplos favores recebidos de sua Santidade, descobri e toquei com as mãos ter-me, no conceito que eu tinha, enganado em muito, visto que a opinião firme e geral é que eu tenha calado convencido pelas vossas demonstrações, as quais são estimadas por alguém como necessárias e insolúveis. E ainda que a crença de que elas sejam assim constitua certo alívio para minha reputação, ainda assim, em geral tanto os especialistas (inteligenti) quanto os não especialistas (non intendenti) formaram de meu saber um conceito bastante tênue, aqueles porque compreendem a pouca eficácia das oposições e, ainda assim, me vêem calar, e estes que, por não serem capazes de julgar a partir de outro que do sucesso, do meu silêncio argumentam também o mesmo. Eu encontrei-me assim posto na necessidade, ainda que, como vedes, bastante tarde e contra a minha vontade, de ter que responder ao vosso escrito.

E adverti, Senhor Ingoli, que eu não empreendo esta empresa porque eu tenha o pensamento ou o desígnio de levantar e sustentar como verdadeira aquela proposição que já foi declarada suspeita e repugnante àquela doutrina a qual por excelência e por autoridade é superior às disciplinas naturais e astronômicas; mas faço-o para mostrar que enquanto eu me ocupava com os astrônomos e os filósofos, não fui nem tão cego de intelecto nem tão débil de razão que, por não ter visto ou compreendido as objeções 
produzidas por vós, eu tivesse ficado na opinião [511] de que a hipótese copernicana pudesse e devesse ser verdadeira e não a outra ptolomaica e comum. Acrescente-se a esta uma outra razão: e ela é que tendo sido feita não pouco estima das razões por vós adotadas mesmo por pessoas de tanta autoridade que puderam estimular a recusa da opinião copernicana feita pela Congregação do Índice; e tendo, por aquilo que entendo, chegado tais escritos a várias nações ultramontanas e talvez até às mãos dos heréticos; parece-me condizente com a minha reputação e também com a de outros, tirarlhes a ocasião de fazer de nossa doutrina um conceito menor que aquele que se deve, quase como se entre os católicos não tenha existido quem tenha conhecido que muito se pode desejar nesses escritos, ou antes, que com base na confiança neles se tenha abraçado a refutação da opinião de Copérnico, sem temer que jamais chegue a acontecer que alguém, daqueles que são separados de nós, possa extrair de sua verdade alguma demonstração segura e concludente ou experiência manifesta. E acrescento mais, que, para confusão dos críticos, entre os quais sinto que aqueles que mais gritam são todos da opinião de Copérnico, penso tratar esse argumento bastante longamente e mostrar-lhes que nós católicos, não por defeito do discurso natural ou por não ter visto quantas razões, experiências, observações e demonstrações tenham visto eles, ficamos na antiga certeza ensinada pelos autores sacros, mas pela reverência que temos dos escritos de nossos Padres e pelo zelo da religião e de nossa fé; de modo que, quando eles tiverem visto que compreendemos muito bem suas razões astronômicas e naturais, antes, mais ainda, outras também de muito maior força que as produzidas até aqui, quando muito poderão taxar-nos de homens constantes na nossa opinião, mas não mais como cegos ou ignorantes das disciplinas humanas; coisa que finalmente não deve importar a um verdadeiro cristão católico; digo, que um herético ria deste porque ele antepõe a reverência e a fé, que se deve aos autores sagrados, a quantas razões e experiências possuem todos os astrônomos e filósofos juntos. Acrescente-se a este um outro benefício para nós, que será o de compreender quão pouco se deve confiar nos argumentos humanos e na sabedoria humana e quanto, por isso, somos devedores das ciências [512] superiores, as quais são as únicas capazes de desanuviar a inépcia de nossa mente e de ensinar-nos aquelas disciplinas às quais jamais chegaríamos por nossas experiências ou razões.

Estes respeitos podem ser, se não erro, não somente desculpas idôneas junto ao universal, mas razões urgentes ainda do ter-me eu resolvido responder a vosso escrito. Quanto depois à vossa pessoa em particular, eu não sei se devo pedir-vos desculpa da muita delonga (posto que vós mesmos pedistes e insististes por resposta) ou se antes eu devo pedir-vos de perdoar-me e de receber benignamente e com ânimo calmo, se talvez muito claramente virdes descobertas aquelas falácias, onde os vossos argumentos haviam conquistado aplausos. Nem deveis negar-me um tal indulto, enquanto 
do meu silêncio de oito anos podeis estar seguro que jamais desejei a diminuição da vossa fama; e da qualidade de minhas respostas podereis compreender que não é nelas, mas nas vossas próprias objeções, que tem raiz aquele fruto que, não sem meu desgosto, poderia talvez amargar-vos em certa parte o gosto: que bem devíeis, Sr. Ingoli (e seja-me permitido, por vossa ingenuidade filosófica e por minha antiga afeição por vós, dizer muito livremente), pondo-vos, como se diz, as mãos no peito, e sabendo consistentemente que Nicolau Copérnico tinha bastante mais anos nessas dificílimas especulações que vós dias consumados, devíeis, digo, aconselhar-vos melhor e não deixar-vos facilmente persuadir de poder aterrar um tal homem e, principalmente, com aquele tipo de armas com as quais o afrontais, que finalmente fazem parte das objeções mais comuns e usuais que se fazem nesta matéria, e se, ainda assim, existir nisso alguma coisa de vosso, esta é de menos eficácia que as outras. Portanto, esperáveis que Nicolau Copérnico não tenha penetrado os mistérios do facílimo Sacrobosco?4 Que ele não tenha entendido a paralaxe? Que ele não tenha lido e entendido Ptolomeu e Aristóteles? Eu não me admiro que tenhais confiado de poder vencê-lo, pois que tão pouco o estimáveis. Mas se vós o tivésseis lido com toda aquela atenção que vos é necessária para bem entendê-lo, quando não fosse por outra coisa, pelo menos a dificuldade da matéria teria de algum modo atordoado em vós aqueles espíritos contraditórios que, [513] antes de tomar uma tamanha resolução, vos teríeis refreado e mesmo totalmente abstido.

Mas já que o feito está feito, vejamos, naquilo que é possível, de prover que vós e outros não multipliquem os erros. Chego, portanto, aos argumentos trazidos por vós para provar que a Terra, e não o Sol, está colocada no centro do universo; o primeiro desses argumentos, tomado da paralaxe do Sol e da Lua, porque é novo e vosso próprio, será por mim mais detalhadamente considerado que os outros comuns e antigos; e porque percebo que tendes necessidade de alguns conhecimentos mais detalhados e exatos, concedei que eu os vá detalhada e exatamente explicando.

Sei que vos é conhecido que nossa visão se faz por linha reta e que, se esta última é prolongada para além do objeto e nela se constituem outros objetos visíveis, todos eles aparecem-nos conjugados entre si, mas as coisas que estão postas fora da referida linha reta, mostram-se separadas dela e postas ou à direita ou à esquerda da linha, segundo estejam colocadas ou deste ou daquele modo. Assim, se alguém, ao olhar, por exemplo, a estrela de Vênus, imaginar uma linha reta tirada do seu olho pelo centro da estrela e prolongada até o céu estelar, aparecer-lhe-á Vênus em conjunção com alguma estrela, se acontecer que alguma esteja naquela tal linha; e se essa tal linha porventura ferir o primeiro grau de Áries, dir-se-á que Vênus aparece em conjunção, ou alinhada, ao primeiro grau de Áries. Além disso, porque raríssimas vezes acontece que dois [observadores] que olhem o mesmo objeto estejam ambos postos em uma mesma 
linha reta com o objeto, mas quase sempre acontece que, estando separados, enviem a visão por linhas diferentes, as quais se encontram nesse objeto e aí se interceptam, e, prolongadas, vão sempre mais afastando-se entre si e, finalmente, acabam terminando, por exemplo, no firmamento em pontos diferentes; assim é que aos dois observadores aparecerá o mesmo objeto em conjunção e alinhado a dois pontos diferentes do céu. Ora, essa diferença de lugar aparente, causada pelas posições diferentes dos dois observadores, é aquela que comumente se chama paralaxe, ou antes, diferença de aspecto.

Passo agora a aplicar essa consideração aos dois objetos visíveis referidos por vós, ou seja, ao Sol e à Lua; os quais, enquanto [514] de diferentes lugares da Terra e muito distantes entre si, forem olhados por observadores diferentes, não há dúvida alguma que aparecerão estar alinhados a muitos lugares diferentes do céu altíssimo; donde, por exemplo, a Lua, que a um observador posto para oriente se mostra sob o primeiro grau de Touro, para outro, no mesmo momento de tempo, que a olhe do ocidente, mostra-se no segundo ou terceiro grau; e, em suma, para tantos quantos forem os lugares diferentes da superfície terrestre a partir dos quais seja olhada, ela mostrar-se-á estar colocada em tantas partes diferentes do firmamento. Ora, porque uma das primeiras intenções dos astrônomos é a de poder determinar com qual lugar do firmamento, para cada tempo dado, essas luminárias estão alinhadas para qualquer observador, constataremos rigorosamente que isso é impossível de fazer-se, se entre os inumeráveis sítios aparentes não se escolhe um fixo e estável, ao qual depois outros [observadores] se referissem e por ele se regulassem. Por isso, convencionaram e estabeleceram que o lugar verdadeiro e real no firmamento, no qual ou sobre o qual devese verdadeiramente dizer estar colocado o planeta, é aquele ponto aonde vai terminar a linha reta que, partindo do centro da Terra, passa pelo centro do planeta; de modo que alguém somente vê a Lua e o Sol no lugar verdadeiro, quando seu olho se encontra em tal linha; a qual, porque vem do centro do globo terrestre, corta a sua superfície em ângulos retos e determina no céu aquele ponto que subjaz perpendicularmente ao vértice desse observador, chamando-se ponto vertical ou, em língua árabe, zênite.

Dois são, portanto, os lugares do planeta no firmamento, ou seja, o aparente e visto, que é aquele que é determinado pela linha reta traçada do olho do observador pelo centro do planeta, e o verdadeiro, que é aquele que é marcado pela linha reta lançada do centro da Terra pelo centro do planeta; e estes dois lugares unem-se e tornam-se o mesmo somente quando o olho do observador está na linha do lugar verdadeiro, que é quando o planeta está no vértice e zênite ; fora daqui, o lugar verdadeiro e o aparente estão sempre separados; e o intervalo que existe entre eles chama-se a paralaxe do Sol ou da Lua. Porque, portanto, a paralaxe não é outra coisa que aquele espaço no céu [515] que está compreendido entre as duas linhas do lugar verdadeiro e do visto, é manifesto que segundo as duas linhas sejam mais ou menos separadas, a paralaxe tornar-se-á 
maior ou menor; de modo que, em suma, a quantidade da paralaxe é regulada e determinada pela quantidade do ângulo que é constituído no centro da estrela por essas duas linhas; ângulo o qual, porque é sempre igual ao outro que lhe é oposto pelo vértice, podemos com a mesma verdade determinar a quantidade da paralaxe do ângulo que as duas linhas traçadas, uma do centro da Terra e a outra do olho do observador, constituem no centro da estrela.

Esse tal ângulo e, em conseqüência, a paralaxe recebe crescimento ou diminuição por duas causas. Uma é o maior ou menor afastamento do observador na Terra com relação à linha do verdadeiro lugar da estrela; e a outra é a maior ou menor altura, ou antes, afastamento, da Terra com relação a essa mesma estrela. E para mais claro entendimento de tudo isso tomem-se as duas seguintes figuras. Na primeira delas, seja o

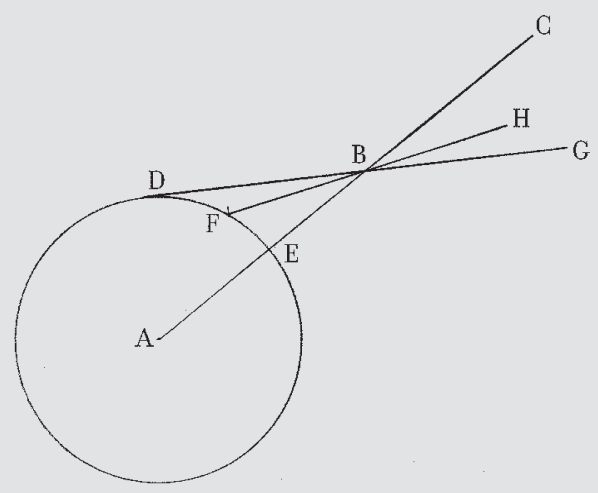
ponto A o centro da Terra e DFE o círculo máximo na sua superfície; esteja em B a estrela e em D o observador; a linha AEBC será aquela do lugar verdadeiro e a DBG aquela do lugar visto; o ângulo da paralaxe será CBG, ou ainda, o outro DBA, que lhe é oposto pelo vértice e, por isso, lhe é igual. Mas se o observador estiver mais próximo da linha do lugar verdadeiro, como, por exemplo, em F, traçada a linha do lugar visto, ou seja, FBH, a paralaxe será menor, ou seja, determinada pelo ângulo HBC, ou antes, FBA. Mas seja, na outra figura, a linha AEBC aquela do lugar verdadeiro, e o ângulo CBG, ou DBA, a quantidade da paralaxe, quando a estrela esteja em B; mas quando ela estivesse em $\mathrm{S}$, isto é, mais próxima da Terra, trace-se a reta DSH, a qual será a linha do lugar visto; e o ângulo CSH, ou ainda DSA, será a quantidade da paralaxe e será maior que o outro DBA, sendo ele externo ao triângulo DSB. Portanto, a maior proximidade da estrela à Terra [516] faz a paralaxe maior; e o considerar se as linhas DB e AB prolongadas para $\mathrm{Ce} \mathrm{G}$ acabam terminando em um orbe próximo ou afastado ou afastadíssimo nada tem a ver com fazer a paralaxe maior ou menor, assim como não altera em nada o ângulo CBG; que é a medida e a quantidade da paralaxe considerada por Copérnico e por todos os outros astrônomos no Sol e na Lua.

Disto pode-se facilmente conhecer o equívoco, o qual, se eu não me engano, encontra-se no argumento para provar que o Sol não pode estar no

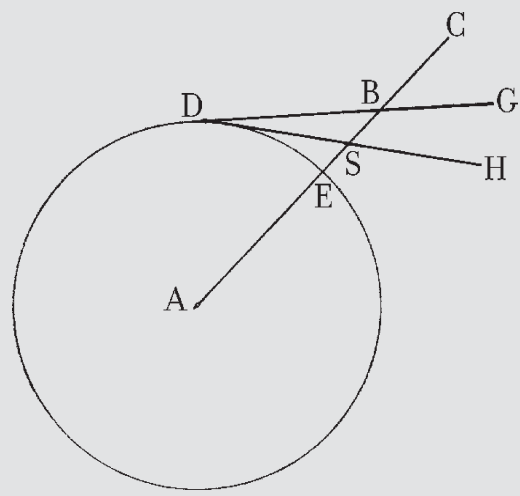


centro do firmamento, argumentais assim: o centro é o ponto mais remoto da superfície da esfera dentre todos os outros contidos no interior dessa esfera; se, portanto, o Sol estivesse no centro, estaria mais afastado desse firmamento do que a Lua; e, por isso, a paralaxe do Sol deveria ser maior que aquela da Lua: mas esta, como afirmam Copérnico e todos os astrônomos, é bastante menor; portanto, o Sol não pode estar em tal centro. Aqui o equívoco é bastante claro, visto que não é o afastamento da estrela ao firmamento ou a qualquer outra coisa que ponhais como término da paralaxe que a torna maior, mas a proximidade dessa estrela ao olho do observador, ou seja, à Terra. Ora, se a paralaxe devia perturbar a posição de Copérnico, era necessário que vós mostrásseis que em tal posição o Sol ficava mais próximo da Terra que a Lua; coisa que ele não disse nem jamais pensou; antes, os intervalos entre os três corpos, Sol, Lua e Terra, ele os toma exatamente os mesmos que os outros astrônomos; e, por isso, o assunto das paralaxes fica o mesmo que anteriormente ad unguem, 5 nem tem qualquer papel na debilitação do sistema de Copérnico.

Este equívoco, até onde eu o compreendo, tem sua origem em um outro paralogismo, que é o seguinte. Vós, ao reterdes sempre cravado na mente que a Terra esteja situada no centro do firmamento, acabais depois (e isso por conseqüência necessária) inferindo dentro de vós, que a Lua, como é muito próxima da Terra, esteja muito mais distante do firmamento que o Sol, que está muito mais afastado da Terra que a Lua; que é depois o mesmo que dizer estar o Sol [517] muito mais próximo do firmamento que a Lua. Ouvindo, então, que os astrônomos observam na Lua uma paralaxe bastante maior que no Sol, formastes em vós o conceito de que o maior afastamento do firmamento seja a causa da maior paralaxe; argumento esse que, todavia, conclui que por isso a Terra, ou seja, o olho do observador, esteja no centro do firmamento, e não de outro modo. Ora, que a Terra, e não o Sol, esteja no centro do universo é aquilo que está em questão; mas vós o supondes conhecido.

Que, portanto, não se siga por necessidade que o Sol possa ser dito mais próximo do firmamento que a Lua, se não se supor antes que a Terra esteja no centro, eu vos explico e, entrementes, advirto-vos de um outro equívoco. Nós, com Ptolomeu e com Copérnico, falamos do firmamento enquanto nele vós quereis marcar a grandeza e a quantidade das paralaxes do Sol e da Lua, as quais não são mais que aquele espaço que fica interceptado entre as duas linhas dos dois lugares, o verdadeiro e o visto. Além disso, o uso primário da paralaxe é para calcular os eclipses do Sol, para cuja precisão a paralaxe da Lua é de suma importância. Tais eclipses fazem-se, como sabeis, somente nas conjunções do Sol e da Lua. Mas quando a Lua está em conjunção com o Sol, ela se encontra, na posição de Copérnico, muito mais afastada do firmamento que o Sol (digo do firmamento, isto é, daquela parte do firmamento na qual vós quereis medir a paralaxe), porque, traçando então do centro da Terra a linha reta pelos centros da Lua e do 
Sol, que é aquela que determina os lugares verdadeiros no firmamento, qualquer pessoa entenderá que o Sol está naquela parte tanto mais próximo que a Lua, quanto é a distância entre a Lua e o Sol: donde, ainda conforme ao vosso próprio conceito, o qual é que a estrela mais remota do firmamento produz uma paralaxe maior que a [estrela] menos remota, a paralaxe da Lua deve ser maior que aquela do Sol. Percebei, portanto, o equívoco que fazeis quando dizeis que o mais remoto de todos os pontos da circunferência do círculo é o centro: pois que qualquer outro ponto que seja, embora esteja mais próximo de alguma parte da circunferência, de outra, entretanto, é outro tanto [158] mais distante, e conduz o caso a vosso desfavor; pois que a parte da circunferência em torno da qual consideramos a paralaxe é aquela da qual o centro está mais próximo que os outros pontos: e digo isso porque nos cálculos dos eclipses lunares, quando a Lua poderia dizer-se mais próxima do firmamento que o Sol, as paralaxes não são consideradas, nem possuem qualquer uso.

Mas, para melhor remover também o equívoco, posto que o firmamento seja fechado dentro de uma superfície esférica (ainda que nem vós nem outro homem no mundo saiba ou possa humanamente saber, não só qual seja sua figura, mas se ele tem alguma figura), qual é a razão que vos persuade que o centro esteja mais afastado daquela que de qualquer outro ponto? Eu, quanto a mim, não creio nessa coisa. Com efeito, quando afirmais que o centro é o ponto mais remoto da superfície, ou entendeis de toda a superfície inteira ou de alguma parte: se é de toda, digo que todos os pontos contidos dentro da esfera são igualmente afastados de toda a superfície; posto que entre cada um desses pontos e toda a superfície intermedia toda a solidez de toda a esfera; mas se entendeis não de toda a superfície tomada conjuntamente, mas de partes tomadas separadamente, a coisa procede ainda mais a vosso desfavor; posto que mais são as partes às quais o centro é mais vizinho que qualquer outro ponto que aquelas das quais ele é mais afastado: o que se pode facilmente demonstrar. Com efeito, seja o círculo $\mathrm{ABCD}$ com centro $\mathrm{E}$ e tome-se um outro ponto qualquer $\mathrm{F}$ e, por ele e pelo centro, trace-se o diâmetro FEA; dividida a EF ao meio no ponto O, trace-se por ele a BOD perpendicular ao diâmetro e as linhas retas $\mathrm{BE}, \mathrm{BF}, \mathrm{ED}$, DF. E porque as duas EO, OB são iguais às duas FO, OB e os ângulos no ponto $\mathrm{O}$ são retos, as bases EB, BF serão iguais, assim também serão iguais ED, DF. Portanto, as linhas traçadas do ponto $\mathrm{F}$ aos pontos $\mathrm{B}$ e $\mathrm{D}$ são iguais ao semidiâmetro; e é manifesto, pela sétima [proposição] do terceiro [livro de Euclides], que todas as outras traçadas do mesmo ponto $\mathrm{F}$ até qualquer ponto da circunferência BCD serão [519] menores que o semidiâmetro; mas todas as outras traçadas do mesmo ponto $\mathrm{F}$ até

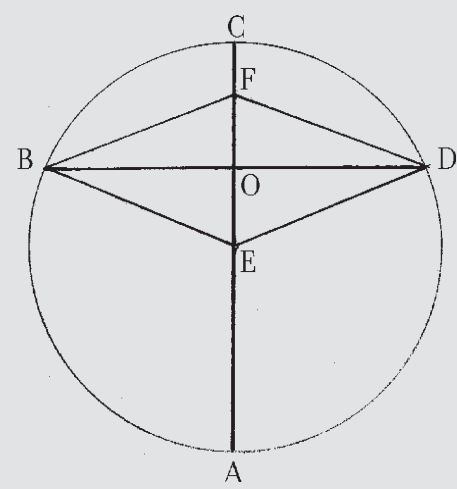


quaisquer pontos da circunferência $\mathrm{BAD}$ serão maiores que as $\mathrm{FB}, \mathrm{FD}$, ou seja, que o próprio semidiâmetro; e porque a porção de círculo BAD é maior que a remanesente BCD (estando naquela o centro), portanto, mais são as partes da circunferência do círculo das quais o ponto F está mais distante que o está o centro que aquelas das quais ele está do mesmo centro mais próximo. E isto que se demonstrou para o círculo, podeis entendê-lo para a esfera.

É, portanto, falsa a suposição de que o centro esteja mais afastado da superfície do que qualquer outro ponto que se queira; antes, todos os outros pontos da circunferência são em conjunto igualmente distantes e, das partes tomadas separadamente, estão em geral mais afastados. Convinha, portanto, para fugir ao equívoco, dizer que o centro estava mais afastado de algumas partes da circunferência que outro ponto dessas mesmas partes. Mas mesmo isso não era suficiente para liberar-vos do erro, como declarei acima e como por vós mesmos (quando o desejo de contradizer não vos tivesse levado um pouco a tomar os termos usuais da arte em sentido diferente do seu próprio) teríeis do vosso próprio falar podido perceber. Vós mesmos escrevestes que o Sol no apogeu tem menor paralaxe que quando está no perigeu; interpretastes depois que o apogeu e o perigeu são o mesmo que dizer próximo e afastado do firmamento; e, entretanto, estes termos referem-se a próximo e afastado da Terra; e o próprio Magino que, nessa ocasião e no lugar por vós citado, trata difusamente das paralaxes, jamais reconhece a sua alteração na oitava esfera, mas sempre na Terra, como também todos os outros astrônomos. Mas e o que mais? Dizei-me, Sr. Ingoli, acreditais que jamais possa acontecer que uma estrela que esteja mais afastada da Terra tenha paralaxe maior que uma mais próxima? Convém que respondais necessariamente que não; onde eu vos faço a segunda interrogação que é se no sistema copernicano a Lua é mais afastada da Terra que o Sol. É necessário que respondais igualmente que não; mas que ficam as mesmas distâncias ad unguem [520] que aquelas do outro sistema ptolomaico. Ora, se tendes, tal como eu creio, sempre entendido essas coisas, não sei como acabastes por escrever que no sistema copernicano, se ele fosse verdadeiro, aconteceria que a paralaxe do Sol seria maior que aquela da Lua. Quem acredita que o maior ou o menor afastamento da oitava esfera faz a paralaxe ser maior ou menor, é necessário que igualmente acredite que a paralaxe e as outras distâncias, que se observam entre as estrelas com quadrantes, sextantes, astrolábios e outros instrumentos, sejam elas também maiores ou menores segundo outros operem com instrumentos maiores ou menores; porque exatamente da mesma maneira consideram-se os graus na circunferência do quadrante que na circunferência do zodíaco ou em outro círculo imaginado no céu. Mas porque a verdade é que tais quantidades medem-se pelos ângulos feitos no centro do instrumento, que se toma ainda como centro dos círculos celestes, e tais ângulos não crescem ou diminuem pelo acréscimo ou diminuição das circunferências sobre as quais 
incidem, por isso as quantidades das paralaxes e dos outros intervalos ficam sempre as mesmas, sejam elas numeradas sobre instrumentos grandes ou pequenos, sejam elas referidas no céu a círculos próximos ou afastados quanto se queira. E se isso não bastar para remover outros dessa opinião, terei por firme e seguro que eles acreditassem que as horas mostradas por um ponteiro de relógio mais longo em uma circunferência maior sejam mais longas que outras que um ponteiro menor mostra em um círculo menor. E mais, vós remeteis a Tycho nas suas tábuas de paralaxes, mas por que não procurastes saber se ele, ao calculá-las, se serve das distâncias à Terra ou antes ao firmamento? Porque vos teríeis percebido de vosso erro; porque teríeis encontrado que jamais se trata do afastamento do firmamento e teríeis assegurado-vos que o colocá-lo três ou quatro ou mil vezes mais próximo ou mais afastado não altera um cabelo a paralaxe. Mas, sem ter visto Tycho ou outros, ainda assim devia ter-vos vindo à mente que em um cálculo exato das paralaxes não podia de modo algum ter lugar a distância do firmamento, a qual é ignota para todos; e aquilo que é ignoto não pode servir como fundamento de doutrina segura.

[521] Resta finalmente, neste vosso primeiro argumento, considerar aquilo que vós escreveis contra quem quisesse dizer que, para liberar Copérnico de vossa objeção, basta que a Lua esteja mais próxima da Terra que o Sol; ao que vos opondes (e também bastante indiretamente) e dizeis que tal solução não vale, porque as paralaxes devem estar entre si como as distâncias, as quais são como 18 para 1; mas as paralaxes estão como 22 para 1; portanto etc. Ora, se acreditais poder concluir contra mim porque as paralaxes não observam aquela proporção que vos parecem que devesse observar, portanto (ficando no vosso modo de discorrer), sempre que a verdade fosse que as paralaxes não devessem observar aquela tal proporção que dizeis, tal como verdadeiramente não a observam, o meu argumento concluiria bem; mas a verdade é que as paralaxes não têm que observar aquela proporção, mas uma outra, que é então aquela que elas verdadeiramente observam: portanto, vós não tendes razão. Além disso, que leviandade há em dizer: "as paralaxes diminuem mediante o afastamento da Terra; portanto, porque tal afastamento é causa da diminuição, as paralaxes devem observar as mesmas proporções que as distâncias"? Qual geometria ensina que os efeitos devem responder proporcionalmente a suas causas? Eu vos poderia mostrar mil particulares contrários; mas por brevidade apresentarei um, que é, entretanto, forçoso que freqüentemente o tenhais tido entre as mãos ao fazer vossos cálculos e cômputos astronômicos. Tomai o círculo, cujo semidiâmetro é $\mathrm{AB}$ e a tangente é $\mathrm{BD}$; e vindo de grau em grau de $B$ para $R$, tracem-se as secantes $A G, A D, A R$.

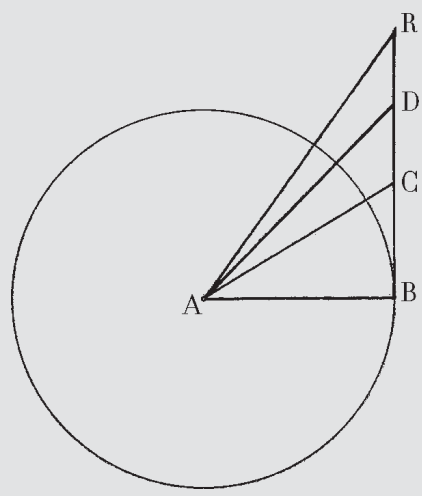


É evidente que o mover o raio para $R$ é causa do fazer crescer as tangentes e as secantes e, por isso, seu crescimento deve ser proporcional aos crescimentos dos arcos; mas os arcos, crescendo de grau em grau, crescem igualmente; portanto, na vossa doutrina, as ditas secantes e tangentes também devem crescer igualmente: coisa que depois é tão falsa que tanto umas como as outras vão continuamente [522] variando a proporção de seus crescimentos, e não só crescem igualmente, mas os crescimentos são 2 e 3 e 4 e 10 e 100 e 1000 e 10000 vezes maiores um que o outro. Agora vedes quanto o vosso discurso afastou-se da boa estrada. Mas direi mais: se as paralaxes devem observar a proporção das distâncias e a paralaxe da Lua é vinte e duas vezes maior que aquela do Sol, e as paralaxes dependem, para vós, dos afastamentos que existem entre os corpos vistos e a oitava esfera, portanto, é necessário que no vosso conceito tivésseis estimado que a Lua esteja 22 vezes mais afastada da oitava esfera do que o Sol, que é o mesmo que dizer que o intervalo entre a Lua e o Sol seja vinte e uma vezes maior que aquele que resta entre o Sol e a oitava esfera, exorbitância mais que máxima, visto que, supondo que uma estrela fixa de grandeza medíocre seja tão grande quanto o Sol, a distância entre o Sol e a oitava esfera será mais de 4,00 vezes maior que o intervalo entre o Sol e a Lua. Vede agora o quanto podem o interesse e o afeto próprios! Afirmo (para vosso mais claro entendimento, e o de outros) que vos parece um absurdo potentíssimo para destruir a doutrina de Copérnico opor-lhe que a sua posição não pode ser verdadeira porque aquela medida que é 22 deveria ser 18; mas depois, na vossa posição e na de Ptolomeu, não vos causa escrúpulo algum que essa mesma medida, que deveria ser 4.00, seja um vinte e um avos menor, ou seja, que aquela que deveria ser 84,00 seja um. E finalmente, Sr.Ingoli, para retirar-vos todo subterfúgio, mas também para liberar-vos da ocasião de poder acrescentar erros sobre erros, ao esforçar-vos em tentar, com distinções ou declarações, mostrar que a paralaxe, entendida daquele e não deste modo, pode fazer que neste e não naquele sentido tenhais falado bem; digo-vos que a paralaxe, da qual falam Copérnico e todos os outros astrônomos, é aquela que se considera no ângulo feito pela intersecção das linhas do lugar verdadeiro e do visto: e esta é sempre a mes$\mathrm{ma}$, tanto no sistema copernicano quanto no ptolomaico; tampouco dela pode-se obter um mínimo minimíssimo subsídio nem a favor nem contra aquela ou esta hipótese; e virdes a campo com qualquer declaração, restrição ou outra fantasia produzir-vos-á um efeito similar àquele que produziu a denúncia daquele que, ouvindo [523] que um tabelião seu inimigo estava encarcerado sob a acusação de falsário e que quando fosse culpado perderia a mão direita, foi com algumas testemunhas, as quais sem qualquer exceção testemunharam que aquele tal tinha andado mascarado, ato que se dizia ser uma falsificação; onde o magistrado com muita risada o licenciou, dizendo-lhe que a direita se cortava dos falsificadores de contratos e de testamentos e não a quem com máscara falseava a sua pessoa e que, portanto, a sua acusação não prejudicava em nada 
ao pobre tabelião, assim como a vossa nada tem a ver com Copérnico. E isso baste quanto a vosso primeiro argumento.

Quanto ao segundo, com o qual pretendeis, juntamente com Sacrobosco, poder demonstrar que a Terra está no centro do firmamento visto que as estrelas fixas, postas em qualquer parte do céu, mostram-se do mesmo tamanho, digo-vos que lhe faltam não uma só, mas todas aquelas condições que são necessárias para concluir bem. E, primeiro, vós supondes que as estrelas do firmamento estejam todas colocadas em um mesmo orbe; o que é tão duvidoso de saber-se, que nem vós nem outros jamais isso provará pela eternidade; e ficando no conjectural e no provável, direi que nem mesmo quatro das estrelas fixas, quanto menos todas, estão igualmente distantes de qualquer ponto que desejásseis tomar no universo. Mas posto ainda que fosse verdade que o firmamento fosse um orbe esférico, com qual certeza afirmais que uma estrela nos apareça sempre da mesma grandeza, a partir do que podeis argumentar que o nosso olho e a Terra estejam no centro de tal orbe? Esta observação está repleta de dificuldades que a tornam incertíssima. Primeiro, pouquíssimas são as estrelas fixas que se vêem quando estão próximas ao horizonte. Segundo, destas últimas os tamanhos são sempre de vários modos alterados pelos vapores e outros impedimentos. Terceiro, quando não existissem tais alterações, que olho livre poderá jamais aperceber-se de uma mutação minimíssima que pode ocorrer em duas ou três ou quatro horas? Ou com qual instrumento se distinguiriam tais minúcias? Ora, os olhos e os instrumentos foram até aqui tão inábeis para juízos semelhantes, que mesmo na determinação do diâmetro aparente das fixas os observadores têm-se enganado em mais de mil por [524] cento; vede, assim, se esses mesmos não se poderão enganar em um por mil e até mais. Quarto, se os próprios autores que põem a Terra no centro afirmam que, por ser o seu semidiâmetro totalmente insensível com respeito ao grande afastamento da esfera estelar, as estrelas não nos aparecem maiores próximas do meio do céu que próximas ao horizonte, ainda que naquele sítio estejam verdadeiramente mais próximas de nós que neste último em quase um semidiâmetro terrestre, deveríeis conceder que seria necessário pôr a Terra muito próxima do orbe estelar, para que a aproximação e o afastamento de uma fixa à Terra feitos pelo movimento diurno (o qual é menor que um semidiâmetro) fizesse uma mutação notável em seu tamanho aparente; mas Copérnico não remove tanto do centro nem aproxima a Terra tanto do orbe estelar, que a aproximação de um semidiâmetro possa causar um crescimento sensível no tamanho aparente de uma estrela, visto que na distância que existe entre a Terra e as fixas pode entrar muitas centenas de vezes a distância que existe entre a Terra e o Sol, sem admitir nenhuma daquelas coisas que para vós, Tycho e outros parecem grandes exorbitâncias; o que, a seu lugar e tempo, mostrarei longamente, mas por ora, para tirar-vos a vós e aos outros do erro, tratarei brevemente de certas coisas, principalmente porque nisso está contida a resposta a uma outra de vossas objeções. 
Encontram esses adversários de Copérnico, por meio de cálculos feitos por eles, que, para querer que o movimento da Terra feito pelo orbe magno, o qual, nos planetas, produz grandíssimas e admiráveis alterações, não causasse algum desses efeitos nas estrelas fixas, seria necessário que o orbe estelar fosse tão afastado, que uma fixa, para mostrar-se visível para nós com o tamanho com o qual se mostra, fosse em si mesma muitas vezes maior que todo o orbe anual, o que seria depois maior em muitos milhares de vezes ao próprio Sol; o que eles reputam ser um absurdo enorme. Mas meus cálculos mostram-me que o assunto procede diferentemente; ou seja, mostram-me que, tomando uma estrela fixa medíocre do tamanho do Sol e não mais, basta, para eliminar todos os inconvenientes que, por seus próprios erros, aqueles atribuíram a Copérnico; e seus erros aconteceram no pôr os [525] tamanhos aparentes das estrelas, tanto fixas quanto errantes, muito maiores que aquilo que são; posição esta falsa que os fez errar de tanto que, onde acreditaram poder com verdade afirmar que Júpiter é 80 vezes maior que a Terra, a verdade é que a Terra é maior que ele trinta vezes (e isto chama-se errar em 24,0.000 por 100). Mas retornando a nosso propósito, digo que medido exatamente o diâmetro de Júpiter, ele chega apenas a 4,o segundos, de modo que o diâmetro do Sol vem a ser 5 o vezes maior que aquele; e o diâmetro de Júpiter é bem dez vezes maior que aquele de uma fixa medíocre (como nos mostra tudo isso um telescópio perfeito), tal que o diâmetro do Sol contém 500 vezes aquele de uma fixa medíocre: do que se segue imediatamente que o afastamento do céu estelar é 5 oo vezes maior que aquele que existe entre nós e o Sol. Ora, o que quereis que faça o remover a Terra do centro do orbe estelar por uma ou duas quinhentésimas partes do seu semidiâmetro, com respeito ao fazer-nos aparecer as estrelas menores no horizonte que no meridiano? E quem será tão simplório que se persuada de que os astrônomos comuns possam conhecer o aumento ou a diminuição de uma tal parte no diâmetro de uma estrela, quando tocamos com a mão que esses mesmos em observações similares enganaram-se tão gravemente, como adverti acima? As objeções, portanto, dos adversários são afastadas, como vedes, bastando tomar as fixas medíocres, como, por exemplo, as de terceira grandeza, iguais em tamanho ao Sol. Mas percebendo com o telescópio outras inumeráveis, bastante menores que aquelas, até mesmo de sexta grandeza, e como podemos razoavelmente acreditar que existem muitas outras não observáveis com os telescópios fabricados até aqui e não existindo, de outro modo, qualquer inconveniente em acreditar que sejam iguais e até mesmo que alguma seja maior que o Sol, em qual altíssima profundidade, em vossa fé, poderemos sem exorbitância afirmar que devem estar colocadas? As fixas, Sr. Ingoli, resplendem por si mesmas, como provei em outro lugar, ${ }^{6}$ de modo que nada lhes falta para poderem ser [526] chamadas e estimadas sóis; e se é verdade, como comumente se estima, que as partes altíssimas do universo sejam receptáculos e habitações das substâncias mais puras e perfeitas, essas 
serão ainda não menos lúcidas e esplendentes que o próprio Sol; todavia, a luz de todas conjuntamente, como também seu tamanho visível, digo ainda de todas tomadas conjuntamente, não chega à décima parte do tamanho visível e da luz que pelo Sol nos é comunicada; e de um e de outro desses efeitos existe uma única razão que é seu afastamento: portanto, qual e quanto devemos crer que ele seja?

Chego agora ao vosso terceiro argumento, tomado de Ptolomeu. Aqui parece-me que, primeiro, devo pôr para vossa consideração que dentre as razões que se produzem em torno desse mesmo problema, algumas são verdadeiras e outras são falsas; e entre as falsas, pode existir talvez alguma que tenha alguma semelhança com a verdade em comparação com outras que, para qualquer raciocínio medíocre, apresentam-se imediatamente como são, ou seja, falsas e fora de propósito. Ora, aconteceu que, ao quererdes reprovar a posição copernicana, produzistes coisas verdadeiramente falsas (não falo dos argumentos teológicos), e a maioria daquele gênero de falsidade que está bastante a descoberto. Dentre aquelas que no primeiro aspecto possuem alguma semelhança de verdade está esta que tomais de Ptolomeu, assim como são as outras produzidas pelo mesmo no seu Almagesto, as quais não apenas possuem aspecto de verdadeiras, mas direi que são mesmo concludentes na posição ptolomaica, mas bem nada concludentes para todo o sistema copernicano. Portanto, direis vós, podem as mesmas proposições concluir e não concluir, ao arbítrio de alguém? Não senhor, tomadas absolutamente e em toda a universalidade da natureza; mas ligadas por vezes a uma outra proposição falsa, podem ser, com aquela suposição, concludentes; um exemplo disso será o argumento que agora temos entre as mãos.

Vós dizeis com Ptolomeu: se a Terra não estivesse no centro da esfera estelar, nós não poderíamos ver sempre a metade dessa esfera; mas nós a vemos; portanto, etc. Que depois aquilo que vemos seja a metade, e não mais ou menos, provais de vários modos: o primeiro dos quais é tomado da observação de duas estrelas fixas opostas entre si, como são [527] o olho de Touro e o coração de Escorpião, das quais, enquanto uma nasce, a outra põe-se e pondo-se uma, a outra alternadamente nasce; argumento necessário de que a parte do céu que está sobre a Terra é igual àquela que está abaixo e, em conseqüência, cada uma é um hemisfério e a Terra está posta no seu centro, já que tal acidente acontece em todos os horizontes. $\mathrm{O}$ argumento é belo e digno de Ptolomeu, e acoplado com uma outra de suas suposições, conclui necessariamente; mas negada esta, o argumento fica nulo; e, na verdade, eu fico maravilhado de que outros astrônomos de grande nome e seguidores de Copérnico tenham tido que afadigar-se não pouco para resolver esta objeção e não lhes tenha vindo à mente a verdadeira e facílima resposta, que consiste em negar aquela outra suposição de Ptolomeu, da qual retira força esse argumento. Por isso, notai, Sr. Ingoli, que é verdade que, nascendo e pondo-se alternadamente em todos os horizontes duas estrelas fixas, deve-se por neces- 
sidade dizer que a Terra está no meio da esfera estelar, sempre, todavia, que a Terra esteja imóvel e que o nascer e o pôr-se derive do movimento e conversão da esfera estelar; mas se nós (como faz Copérnico) fizermos ficar parada a esfera e girar sobre si mesmo o globo terrestre, pondo-o aonde bem quiserdes, sempre acontecerá com as duas estrelas aquilo que se disse, ou seja, o nascer e o pôr-se alternadamente. E para um mais claro entendimento, seja a esfera estelar, cujo centro é D e a Terra A esteja afastada o quanto se queira desse centro; e seja o horizonte segundo a linha reta BC. Ora, se nós, estando parados a Terra e o horizonte, supusermos que a esfera estelar move-se em torno do seu centro D e que uma estrela nasce em $\mathrm{C}$ enquanto a outra põe-se em B, é evidente que, quando a C estiver em B, a B não terá retornado a $\mathrm{C}$ (sendo o arco sobre a Terra, CEB, menor que o restante abaixo da Terra), mas estará em $\mathrm{S}$ (suposto o arco BS ser igual ao arco CEB): tardará, portanto, a estrela $\mathrm{B}$ a nascer, depois do pôr-se da C, tanto quanto é o tempo do arco SC. Mas

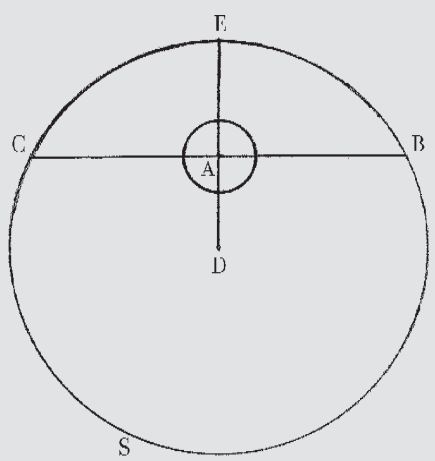
suponhamos agora que a esfera estelar esteja fixa e que a Terra move-se sobre si mesma, a qual levará consigo o horizonte CB: não há dúvida [528] alguma que, quando o término B do horizonte estiver em $\mathrm{C}$, o outro C estará em B; e onde antes, entre as duas estrelas C e B, uma estava no término oriental e a outra no ocidental, feita tal conversão da Terra, retornarão no mesmo momento de tempo invariavelmente nos mesmos términos; tal que, como vedes, esse nascimento e ocultamento invariáveis nada prova acerca do sítio da Terra. Como tampouco daquilo que acrescentais, ou seja, que do marcarse no círculo vertical sempre 90 graus do zênite até o horizonte, pode-se inferir que vejamos a metade do céu; porque, representando, na mesma figura, a linha BC um horizonte qualquer, se do centro A se levantar sobre BC uma perpendicular que irá terminar no ponto vertical, esta conterá daqui e dali dois ângulos retos, cada um dos quais com 90 graus. Aquilo depois que sejam os dois arcos BE, EC, nem se vê, nem se sabe, nem se pode saber, nem serve para nada sabê-lo. Falso é igualmente aquilo que acrescentais a seguir, ao dizer que, quando a Terra não estivesse no centro, não se poderia ver a metade do céu; com efeito, posto que o céu fosse esférico e a Terra estivesse afastada do centro, ainda assim veriam a metade do céu todos aqueles habitantes da Terra cujo horizonte passasse pelo centro do céu.

Aquilo que acrescentais depois para responder à resposta daqueles que dissessem que aquela parte do céu que vemos é insensivelmente mais ou menos o exato hemisfério, porque o orbe magno deferente da Terra é de tamanho insensível com respeito à imensidão da esfera estelar, não conviria que fosse por mim considerado de outro modo, já que outra razão vem por mim extraída do mesmo efeito, isto é, o existir 
o movimento diurno da Terra e não o do céu; todavia, não quero deixar de considerar alguns particulares dignos de serem considerados. E, primeiro, a afirmação que fazeis com tanta resolução, apoiado na autoridade de Tycho, segundo a qual, para querer que o orbe magno de Copérnico fosse insensível com respeito ao tamanho imenso da esfera estelar, seria preciso que essas estrelas estivessem afastadas 14 mil semidiâmetros desse orbe magno, que são então aqueles 16 milhões e meio de semidiâmetros terrestres, é verdadeiramente dita com muita confiança e atribuis muito à simples autoridade de um homem, usando-a para reprovar conclusões tão grandes na natureza. Se o presente lugar e a qualidade das coisas das quais tratamos o permitissem, eu vos poderia [529] mostrar o quanto neste particular enganou-se Tycho e como ele não produz coisa alguma de importância contra Copérnico, mas antes mostra que não chegou a formar-se a verdadeira idéia do sistema copernicano, nem quais são as aparências que se devem ver ou não ver nas estrelas fixas mediante o movimento anual atribuído à Terra. Mas acerca disso ouvireis em outra oportunidade; por ora, para que não pareça que eu fuja da força de quanto aduzis, suponhamos que seja verdadeiro que o orbe magno encontre-se insensível com respeito à esfera estelar e que para mostrar-se isso seja necessário que as fixas estejam afastadas 16.506.000 semidiâmetros terrestres: qual é a impossibilidade e o inconveniente que encontrais, Sr. Ingoli? Parece-me que toda a inconveniência esteja na imaginação dos homens e não na própria natureza; e para mostrar que isso seja verdade, iremos examinando os absurdos que colocais em campo.

Primeiro, dizeis que, posta tal imensidão, o universo seria assimétrico. Esse termo assimétrico, se vós, enquanto geômetra, o tomais no seu verdadeiro significado, quer dizer incomensurável; e aqui não se pode fugir de um dentre dois erros; com efeito, sendo a incomensurabilidade uma relação que ocorre entre dois termos, não trazeis senão um, pois que não dizeis ao que essa imensa mole resulta incomensurável; mas mesmo se dentro de vós quisestes entender que, comparando o orbe estelar com o deferente da Terra, ele seria incomensurável com aquele, não deixastes de errar menos, pois que vós mesmos colocastes entre os números, isto é, entre os fatos comensuráveis, os seus semidiâmetros, dizendo que aquele continha este tantas vezes; e se os semidiâmetros são comensuráveis, muito mais sê-lo-ão as suas esferas. Mas se tomando o termo assimétrico impropriamente, tivésseis querido entender aquilo que dizemos desproporcionado, a afirmação também é arbitrária e sem necessidade de conseqüência. E não sabeis que ainda não se decidiu (e acredito que jamais o será decidido entre as ciências humanas) se o universo seja finito ou infinito. E dado que verdadeiramente fosse infinito, como poderíeis dizer que o tamanho da esfera estelar fosse desproporcionado com relação ao orbe magno, se esta mesma com respeito ao universo seria muito menos que um grão de trigo com respeito a ele? Mas posto ainda que o universo fosse finito e terminado, que razão teríeis de dizer [53o] que a esfera estelar seria despro- 
porcionada com repeito ao orbe magno da Terra, salvo o de dizer que acabaria por contê-lo muitas vezes, compreendendo o seu diâmetro 14 mil vezes aquele do orbe magno? E se esta razão vale, desproporcionadas serão todas aquelas coisas que, sendo do mesmo gênero, uma seja maior que a outra tantas ou mais vezes; e assim, porque nos mares existem peixes tão pequenos que uma baleia pode conter muitos mais e um elefante muito mais peixinhos, portanto, e as baleias e os elefantes são animais desproporcionados e, por isso, também na vossa opinião, não se encontram no mundo, porque tais desproporções não são admitidas na natureza. Além disso, o Sol (como eu já disse) não tem qualquer condição pela qual o possamos separar do conjunto das outras estrelas fixas, de modo que dizer que cada uma das fixas seja um sol é uma coisa razoabilíssima. Começai agora a considerar quanto espaço no mundo atribuís ao Sol para seu refúgio e habitação próprios, no qual ele fique solitário e livre das outras estrelas que lhe são consortes; considerai depois a inumerável multidão das estrelas e ide atribuindo a cada uma, como patrimônio seu, outro tanto de espaço; que absolutamente vos encontraríeis na necessidade de fazer toda a esfera delas bastante maior do que aquilo que vos parece agora uma vastidão excessiva. Quanto a mim, enquanto vou considerando o mundo que é conhecido por nossos sentidos, não posso absolutamente dizer se é grande ou pequeno; direi antes que seja grandíssimo em comparação com o mundo das minhocas e de outros vermes, os quais, não tendo outro meio de medi-lo que o sentido do tato, não o podem estimar maior que aquele espaço que ocupam; e não me causa repugnância que o mundo conhecido pelos nossos sentidos, em comparação com o universo, possa ser tão pequeno como o mundo dos vermes com respeito ao nosso. Quanto depois àquilo que o intelecto, para além dos sentidos, possa apreender, o discurso e minha mente não se sabem acomodar a concebê-lo nem finito nem infinito; e, por isso, nisto remeto-me àquilo que estabelecem as ciências superiores. Portanto, o julgar excessiva uma tal imensidade é efeito de nossa imaginação e não defeito da natureza.

O que escreveis a seguir, isto é, que um tal afastamento das estrelas fixas, quando existisse, destruiria o poder que elas têm de operar [531] nestas coisas inferiores (o que confirmais depois com o exemplo da operação do Sol, tão diminuída devido ao seu afastamento de vosso vértice no inverno, ainda que o afastamento seja pequeníssimo em comparação com a distância das estrelas fixas) para falar livremente, não desejaria, para a vossa reputação, que o tivésseis escrito e, principalmente, conformando-o com o exemplo do Sol. Com efeito, ou tal exemplo está a vosso favor ou não: se não, já confessastes o erro; mas se o estimais propositado, incorreis em muitas outras deficiências maiores. E, primeiro, que possais juridicamente dizer que a ação do Sol invernal e distante seja débil supõe terdes provado aquela do verão, quando ele está próximo; pois, quando a ação tivesse sido sempre do mesmo vigor, jamais poderíeis dizer que esta ou aquela era fraca; no exemplo, supõe-se portanto por necessidade terdes vós 
verificado o efeito do Sol em duas distâncias; e assim, para poder com tal semelhança argumentar para as estrelas, é preciso tê-las tido em dois afastamentos diferentes. Estes dois afastamentos diferentes são um, o vosso, e o outro, aquele de Copérnico; e porque dizeis que o copernicano não é apto para a ação, é preciso que suponhais que a ação se faça com o vosso. Mas isto é o que está em questão e o vosso argumento comete uma petição de princípio, porque eu com tanta razão posso dizer que o afastamento das fixas é tanto quanto lhe atribui Copérnico e é exatamente quanto é necessário para que as estrelas operem do modo como operam; e se dizeis que com tal afastamento não poderão operar, eu com não menor razão digo-vos que se a distância tivesse sido menor, teriam elas operado com tanta violência que teriam destruído o mundo. É forçoso que, quando pela primeira vez chegou-vos ao ouvido a novidade desta hipótese copernicana, formastes vós o conceito de que, para dar-lhe lugar na natureza, fosse necessário ampliar desmesuradissimamente o orbe estelar, operação esta que não podendo estar na alçada de Copérnico nem de outro homem, confirmou-vos a antiga opinião anterior, na qual fixamente vos mantendes. Esses argumentos, enquanto fundamentados em imaginações vãs, não se devem, portanto, produzir nas questões das coisas reais e máximas; e muito menos se deve dizer finalmente ter solidamente demonstrado e concluído grande coisa.

[532] Quanto ao exemplo do Sol que aquece mais no verão que no inverno, por estar então mais próximo de nosso vértice, o que produzis para autorizar vossa proposição, se eu não me engano, ou não se adapta bem ao conceito exemplificado, ou antes é diretamente contrário a vós. Com efeito, se atribuís maior ou menor operar à maior ou menor elevação em direção ao vértice, isso é fora de questão em tudo e por tudo, porque a ampliação da esfera estelar não aumenta ou diminui a declinação das estrelas do vértice, mas retém-nas no seu estado. Mas se quereis reconhecer a ação do Sol pela aproximação ou afastamento da Terra, o Sol está muito mais afastado no verão que no inverno, encontrando-se naquela época em torno de seu auge; tal que se queríeis enunciar para as estrelas fixas em conformidade com a experiência e com o exemplo do Sol, devíeis dizer que afastá-las o quanto diz Copérnico, tê-las-ia feito não menos eficazes, mas muito ativas, e os seus influxos, como as pedras ou o granizo que caem das regiões mais altas, muito vigorosos e, em suma, mais aptos à destruição que à conservação das coisas terrestres. E eis, Sr. Ingoli, os frutos que nascem de argumentos feitos sobre fantasias vãs e sobre conceitos sem coerência e sem fundamento.

Resta que consideremos o quanto fica bem resolvida por vosso argumento a outra parte de vossa ilação, ou seja, que as estrelas fixas deveriam ser maiores que o orbe magno, suposto um tal afastamento. Mas já vos disse acima, no argumento que fazem Tycho e outros para resolver tal exorbitância, existirem muitas falácias, as quais em outro lugar revelei, e por ora digo-vos que, dado, como dizeis, que para mostrar-nos as 
fixas tão grandes que subtendessem a três ou a dois minutos, postas em tal afastamento, seria preciso que fossem tão grandes quanto o orbe magno, não se segue, por isso, que em efeito elas sejam tais, visto que seu diâmetro aparente não ocupa nem mesmo a sexagésima parte de três minutos; assim, disto já se faz evidente que Tycho e vós fazeis a vosso arbítrio e por não ter bem marcado a grandeza aparente das fixas, a esfera estelar estar 60 vezes mais afastada do que é preciso para eliminar a posição de Copérnico: e isso [533] não é nem um corte nem uma diminuição de pouca monta, digo, de diminuir a distância por vós condenada mais que 98 por 100. Que eu tenha, portanto, dito que uma fixa subentenda a dois minutos, como vós me impondes, com a vossa paz, não pode ser verdadeiro; porque faz muitos anos que eu observei sensivelmente que nenhuma fixa subentende nem mesmo 5 segundos, e muitas nem mesmo 4 e inumeráveis nem mesmo 2.

Quanto ao quarto argumento, no qual reprovais o sistema copernicano dizendo, com a autoridade de Tycho, que a excentricidade de Marte e de Vênus são diferentes daquilo que pôs Copérnico, e igualmente que o auge de Vênus não é imóvel, assim também acreditais com ele, parece-me que quereis imitar aquele que queria arruinar desde as fundações a sua casa, dizendo que era de arquitetura falsa e inabitável, somente porque o caminho tinha fumaça; e tê-lo-ia feito, se um seu compadre não o advertisse de que bastava acomodar o caminho, sem destruir o resto. Digo-vos assim, Sr. Ingoli: dado que Copérnico se enganasse naquela excentricidade e naquele auge, emende-se isso, que nada tem a ver com os fundamentos e com a máxima estrutura de toda a construção. Se os outros astrônomos antigos tivessem tido vosso humor, isto é, de pôr por terra tudo aquilo que estava construído toda vez que se encontrava algum particular que não correspondesse à hipótese tomada por alguém, não apenas não se teria edificado a grande construção de Ptolomeu, mas ter-se-ia ficado sempre a descoberto e em ignorância das coisas celestes; e tendo suposto Ptolomeu que a Terra está imóvel no centro, de tamanho insensível com respeito ao céu, o Sol e o firmamento móveis etc e dito depois, por exemplo, que os anos eram todos iguais entre si, vós, encontrada a desigualdade dos anos, teríeis atirado para o alto o Sol, a Terra e o céu e negado tudo aquilo que deles tinha sido até então tomado como verdadeiro. Se os pintores, a cada pequeno erro que lhes fosse mostrado em um dedo ou em um olho de uma figura, tivessem que dar branco a toda a tela, muito tarde ver-se-ia representada uma estória inteira. Não foi por ter conhecido uma certa falácia pequena em algum movimento particular de um planeta que Copérnico induziu-se a refutar [534] o sistema ptolomaico, mas por uma incongruência máxima na estrutura de todos os orbes dos planetas entre si, impossível de admitir-se, e por outras muitíssimas exorbitâncias máximas, as quais eram todas resolvidas em seu sistema. Replico, portanto, que, se para cada acidente particular que se vá descobrindo como novo em alguma parte do céu, deve-se mudar 
toda a estrutura do mundo, jamais se chegará ao cabo de nada; porque vos asseguro que jamais se podem observar tão exatamente os movimentos, os tamanhos, as distâncias e as disposições dos orbes e das estrelas que não tenham continuamente necessidade de correção, mesmo quando todos os vivos fossem Tycho e mais de 100 vezes Tycho. E não creias que não fiquem no céu movimentos, alterações, anomalias e outras coisas ainda não observadas nem conhecidas e, talvez, nem observáveis nem explicáveis por sua própria natureza. E quem vos assegura que os movimentos dos planetas não sejam todos incomensuráveis entre si e, por isso, capazes, antes necessitados, de uma eterna emenda, pois que não os manejamos a não ser enquanto comensuráveis? Mas tratando-se de dilemas máximos e que necessariamente devem ser ou deste ou daquele modo, nem se pode recorrer a um terceiro caso, como são precisamente se o Sol se move ou está parado, se a Terra se move ou não, se está no centro ou fora, se o orbe estelar gira ou está imóvel, destes pode-se asseverar com alguma resolução, e tampouco as conclusões por eles afirmadas estão depois submetidas a cada novidade particular que se descubra e exista nos próprios movimentos dos planetas. Mas deixai estar os fundamentos da construção copernicana e encurtai a vosso modo a excentricidade de Marte e de Vênus e movei o seu auge, que são coisas que nada têm a ver com a estabilidade nem com o lugar do Sol e da Terra.

Chego agora aos dois argumentos que chamais físicos, os quais me parecem abundar em paralogismos daquele gênero que supõe como verdadeiro aquilo que se disputa; e creio que tais falácias nascem em vós porque não vos podeis despojar a mente de alguns termos e de algumas proposições com as quais há muito vos habituastes.

Vosso primeiro argumento tem esta forma: nós vemos, dos corpos simples, os maiores e graves ocuparem os lugares inferiores $\left[5^{3}{ }_{5}\right]$ (como se vê fazer a terra com respeito à água e a água com respeito ao ar); mas a Terra é um corpo mais denso que o Sol e o lugar inferior no universo é o centro; portanto, a Terra, e não o Sol, ocupa o centro.

Aqui considero primeiramente que, quando dizeis e exemplificais com a água, o ar e a terra que os corpos mais graves ocupam o lugar inferior, é preciso que por estes dois termos, inferior e superior, não entendais outro que aquilo que nos está sob os pés, para o centro do globo terrestre, e aquilo que está acima da cabeça, para o céu; pois que, quando por inferior entendeis o centro do universo, o paralogismo já estaria em campo, porque viríeis a tomar como evidente aquilo que está em questão, ou seja, que a Terra estivesse colocada no centro do universo. Além disso, essa inferioridade é finita e terminada no centro da Terra, não se estendendo ao infinito, como faz a superioridade; porque uma linha reta perpendicular à superfície terrestre, que passa por nossa cabeça e por nossos pés, pode ser prolongada ao infinito, que sempre adquirirá partes superiores; mas não se pode fazer isso na direção do centro, porque a linha vai bem para as partes inferiores até que chega a esse centro, mas prolongando-a para além, 
começa a ir para as partes superiores. Uma disposição análoga pode-se, com outra tanta razão, afirmar que se encontra na Lua, no Sol, em Vênus, em Júpiter e em qualquer outra estrela, as quais, sendo de figura esférica, possuem o seu centro e as partes em torno dele igualmente dispostas e inclinadas a moverem-se para ele, quando não estivessem afastadas; tal que, na Lua, no Sol e nas outras estrelas, o lugar inferior é o seu centro, o superior é para a superfície e, para além dela, para o céu ambiente. E não apenas podemos considerar uma tal superioridade e inferioridade nos referidos corpos sólidos mundanos, mas ainda nos orbes e nas esferas que giram em torno de qualquer ponto; e assim, os orbes das quatro medicéias, que giram em torno de Júpiter, terão o centro deste como seu lugar inferior e aquilo que está fora desses orbes será, para elas, superior e aquilo que é inferior para a Terra, ou seja, o seu centro, para as medicéias, é superior. Um tal lugar inferior terão ainda os orbes dos outros planetas e esse será o [536] centro de suas circulações e o seu lugar superior estará para além dos seus orbes, para o restante do céu ambiente. Se convém então para a universalidade das estrelas fixas designar um lugar inferior, isto é, um centro, e um superior, ou seja, para as partes externas, é duvidosa a determinação; mas na ambigüidade parece muito mais razoável o não do que o sim, visto que (como já disse acima) eu não creio que elas estejam todas dispostas em uma superfície esférica, tal que elas estejam igualmente distanciadas de um ponto determinado, como do centro de seu orbe; e só Deus sabe se mais que três se encontram igualmente afastadas de um mesmo ponto. Mas suponhase, por vossa graça, que mesmo essas fixas estejam todas dispostas a igual distância de um só centro, tal que teremos na universalidade do mundo tantos centros e tantos lugares inferiores e superiores quantos são os globos mundanos e os orbes que giram em torno de pontos diferentes.

Retomemos agora vosso argumento, no qual, primeiramente, é necessário ou que pequeis quanto à forma ou que, quanto à matéria, nada se conclua para o vosso propósito. Porque, para não pecar na forma, é preciso ordená-lo assim: dos corpos simples (como são o ar, a água, a terra) os mais densos e graves ocupam as partes mais baixas, ou seja, mais próximas ao centro da Terra, como nos mostra a experiência, sendo a água superior à terra e o ar à água; mas a Terra é mais densa e grave do que o Sol; portanto, a Terra, e não o Sol, ocupa as partes inferiores, isto é, aqueles lugares inferiores que é manifesto serem ocupados pela terra em relação à água e ao ar; de modo que o argumento acaba por não concluir outro senão que a Terra, e não o Sol, ocupa o lugar inferior e mais próximo ao próprio centro da Terra; o que vos concedo e tê-lo-ia concedido até mesmo sem o silogismo. Mas se vós, na conclusão, por lugar inferior quiserdes entender não, como nas premissas, o centro da Terra, mas o centro do universo, ou fareis o silogismo de quatro termos, equivocando o centro da Terra com aquele do universo, ou suporeis como conhecido aquilo que está em questão, ou seja, que a Terra, 
enquanto corpo gravíssimo, ocupa o centro do universo; e eu, se vos for lícito passar do centro da Terra àquele da esfera estelar, com não $\left[5^{3}{ }_{7}\right]$ menor razão, poderei concluir que a Terra ocupa o centro de Júpiter ou da Lua, porque estes também são no mundo lugares inferiores, não menos que o centro da Terra.

Mas vós direis ter suposto nas premissas, como não conhecido por si, que os corpos mais densos e graves ocupam o lugar inferior do universo, mas como demonstrado pelo exemplo do ar, água e terra, dos quais a terra em si mesma ocupa o lugar mais baixo que existe; e se tal foi o vosso intuito, ainda assim errais mais gravemente em muitos outros particulares. E, primeiro, será preciso que se tenha posto nesses corpos mundanos duas inclinações: uma, das suas partes, as quais têm gravidade, isto é, inclinação para os próprios centros de seus globos; e a outra, desses globos totais para o centro do universo; porque assim, e não de outro modo, as partes da terra e da água conspirarão para formar o seu globo e esse depois para ocupar o centro do mundo. E nenhuma razão teríeis de não dever pôr as mesmas condições na Lua, no Sol e nos outros globos mundanos, em cujas partes não podeis dizer que falte aquela mesma inclinação de conspirar para formar o seu globo que reconheceis nas partes da Terra para formar o seu; e se essa mesma inclinação é suficiente para fazer a Terra desejar o centro do universo, a mesma operará o mesmo nos outros globos; tal que, sendo verdadeira esta filosofia, será preciso dizer que todos os globos mundanos, enquanto densos e graves, possuem a inclinação para o lugar baixo do universo, isto é, para o centro; e assim, para dar-vos todas as facilidades possíveis, poder-se-ia dizer que a Terra, por ser mais densa e grave que a Lua, que o Sol e que as outras estrelas, ocupa dito centro; mas os outros, por que não caem em cima da Terra, para avizinhar-se quanto poderiam ao desejado centro? Não vos dais conta (e seja este outro erro) que, para concluir, onde dizeis na premissa menor: "mas a Terra é um corpo mais denso e mais grave que o Sol", digais que não só a Terra, mas também a água e o ar sejam corpos mais densos e graves que o Sol, por que também eles estão para vós no lugar inferior? Coisa da qual creio que jamais persuadireis alguém, nem mesmo vós mesmos [538], interiormente falando. Mas o que digo? Vós até vos encontrastes estar persuadido, e quisestes persuadir também a mim, da autoridade de Aristóteles e de todos os peripatéticos, que dizem que os corpos celestes não possuem gravidade alguma. Ora, aqui, antes que eu passe além, digo-vos que, nas coisas naturais, a autoridade dos homens não vale nada; mas vós, como legista, mostrais fazer disso grande capital; mas a natureza, meu senhor, burla-se das constituições e decretos dos príncipes, dos imperadores e dos monarcas, e diante das exigências deles, ela não mudaria um jota de suas leis e estatutos. Aristóteles foi um homem, viu com os olhos, escutou com os ouvidos, discorreu com o cérebro. Eu sou homem, vejo com os olhos e muito mais do que ele viu: quanto ao discorrer, creio que ele discorresse sobre mais coisas que eu; mas se discorreu mais ou melhor 
que eu em torno daquelas que ambos discorremos, mostrá-lo-ão as nossas razões e não a nossa autoridade. Vós direis: "um tal homem, que teve tantos seguidores?" Mas isso não é nada, porque a antiguidade e o número dos anos passados dão-lhe o número das adesões; e ainda que o pai tenha vinte filhos, nem por isso se pode necessariamente concluir que ele seja mais fecundo que aquele seu filho que tem um só filho, quando o pai tem 60 anos e o filho 20. Mas retornemos à questão.

Vós acrescentais aos erros de Aristóteles um erro maior, que é também aquele de supor verdadeiro aquilo que se disputa. Primeiro concluiu Aristóteles, no seu filosofar, que a Terra, enquanto gravíssima, ocupasse o centro da esfera celeste; e depois disso, vendo que a Lua, o Sol e os outros corpos celestes não caíam para este, que ele estimava ser o apetite de todos os corpos graves, concluiu que àqueles falta a gravidade. Mas vós agora, cometendo o círculo, supondes como conhecido que aos corpos celestes falta a gravidade, para provar aquilo que serviu como prova de tal falta, ou seja, que a Terra está no lugar inferior do mundo e que ela aí está por ser grave. O erro comum a vós e a Aristóteles é o seguinte: quando dizeis "dos corpos graves, a inclinação própria e natural é ir para o centro", ou entendeis por centro o ponto do meio do corpo grave total, o qual é dos corpos terrestres o centro da Terra, ou entendeis o centro de toda a esfera mundana: se o entendeis [539] do primeiro modo, digo que a Lua, o Sol e todos os outros globos do mundo não são menos graves que a Terra e que todas as suas partes conspiram para formar o próprio globo, de modo que, quando outros separassem deles uma parte, ela retornaria ao seu todo, daquele modo que vemos fazer as partes da Terra, nem jamais provaríeis o contrário; mas se vós o entendeis do segundo modo, digo-vos que nem mesmo a Terra tem qualquer gravidade, nem aspira ao centro do mundo, mas está em seu lugar, como a Lua no seu.

Além dessas coisas, eu vos vejo, Sr. Ingoli, envolto em um estranho labirinto, justamente com os vossos peripatéticos, no encontrar e determinar onde esteja esse tão prezado centro do universo. Aristóteles estimou que ele é o ponto em torno do qual girem todos os orbes celestes; digo não tanto a esfera estelar, mas os orbes de Saturno, Júpiter, Marte e todos os outros planetas. Assim, considerando ele todos os orbes serem concêntricos, estimou poder designar o centro da esfera estelar na medida em que lhe parecia poder asseverar que dos planetas e da esfera estelar ele era o mesmo [centro]; pois que, quanto ao orbe estelar por si mesmo, difícil, ou antes, impossível, era, devido a sua desmesurada vastidão, poder-lhe encontrar o meio. Foi, portanto, absolutamente reconhecido por Aristóteles como centro do universo aquilo que é o centro dos orbes dos planetas e neste ele colocou a Terra. Ora, na nossa época, que não é a Terra, mas o Sol que está colocado em tal centro, é mais claro e evidente que o próprio Sol, assim como creio que vós também entendeis; todavia, ainda que vós toqueis com a mão ter Aristóteles errado em muito na realidade do fato, procurais ainda (movido por 
inveterada afecção) manter em pé sua afirmação com palavras e esforçai -vos antes em ir pondo o mundo de cabeça para baixo para encontrar um centro para o universo (já que aquele de Aristóteles está perdido), ao invés de confessar o erro, e confiais e esperais mais ajuda para vossa causa da autoridade de um homem do que temeis a força suprema da natureza e da verdade. Se algum lugar do mundo pode chamar-se seu centro, este é o centro das conversões celestes; e neste é conhecido por qualquer pessoa que entende desses assuntos encontrar-se o Sol e não a Terra.

[540] Explicadas essas coisas, não vale nada fazer o Sol mais ou menos denso e grave que a Terra, coisa que nem eu nem vós sabemos, nem podemos seguramente saber, mas em opinião crerei antes que sim do que não; e isso também na doutrina peripatética, a qual considerando os corpos celestes inalteráveis e incorruptíveis, e a Terra o contrário, parece que essa densidade e essa solidez das partes atribuam mais e com uma maior duração do que faz a menor densidade e fixidez, porque, por tais qualidades vemos o ouro, gravíssimo entre todas as matérias elementares, e os diamantes solidíssimos e outras gemas aproximarem-se mais da incorruptibilidade que os outros corpos menos graves e menos fixos. Quanto depois a esses nossos fogos, aos quais, por serem lúcidos, assemelhais o Sol e queríeis, em conseqüência, inferir que, assim como aqueles são de substância tênue rara e leve, assim também deveria ser o Sol, parece-me que não discorreis solidamente, porque eu, ao contrário, com um argumento bastante mais verossímil, poderei dizer que, vendo como os nossos fogos, por serem de matéria tão rara, são ainda de duração brevíssima ou mesmo instantânea; assim, ao contrário, como supondes o Sol, juntamente com Aristóteles, eterno e incomensurável, é preciso que ele seja de uma substância densíssima e solidíssima; além do que creio que o seu resplender seja diferentíssimo do resplender de nossas matérias ardentes. Que vós, por último (o que fazeis no fim de vosso argumento), acrescenteis as costumeiras autoridades de filósofos para provar-me que o centro tenha de chamar-se a parte ínfima e a superfície, ou antes a circunferência, a parte suprema, respondo-vos que essas são palavras e nomes que resultam em nada e nada têm a ver com pôr as coisas no ser, porque tanto vos negarei estar a Terra no lugar ínfimo, quanto estar no centro. E se mesmo assim, no vosso conceito, esse nome de centro parece-vos que deve ter a força de atrair-vos a Terra, por que não o colocais no firmamento, no qual existem centros aos milhares, sendo que cada estrela é um perfeito globo e cada globo tem o seu centro?

Vejamos, finalmente, o argumento retirado da peneira, ao qual, se vós (como eu creio) prestais fé, prego-vos que o mantenhais mesmo depois que eu vos tiver mostrado que ele prova completamente o oposto daquilo que vos parece que ele prova agora; e não queirais fazer aquilo [541] que fazem os disputadores mais modernos, que primeiro imprimem-se na mente a conclusão, sem ouvir outras razões ou demonstrações, e feita a impressão, a cada razão bem tola e grosseira que venha em confirmação 
dão um assentimento total e liberalíssimo e, ao contrário, àquelas demonstrações contrárias, por mais que sejam evidentes e concludentes, são eles imóveis e não persuadíveis, tendo-se formado esse conceito de que o verdadeiro e perfeito filosofar seja o jamais deixar-se convencer por nenhuma razão ou experiência, ainda que claríssima. Vós dizeis que ao movimento circular da peneira os pedacinhos de terra entre o trigo retiram-se para o centro dela e, por isso, que de modo similar a Terra, quase que peneirada pela circulação do céu, já deve ter sido empurrada para o centro desse céu. Que valha a similitude; mas adverti, Sr. Ingoli, que o peneirador peneira o grão, ele não gira de outro modo a peneira em torno de seu centro nem pouco nem nada; o que é evidente, porque, retendo ele as mãos sempre no mesmo lugar da peneira, é impossível que ela pudesse girar em torno de seu centro sem que as mãos ou os braços do peneirador não impedissem. O movimento da peneira nessa operação é que ela vem agitada e movida de tal modo que o seu centro caminha pela circunferência de um círculo imaginário, paralelo ao pavimento, cujo centro fica imaginariamente suspenso no ar entre os braços e o estômago do peneirador e, devido a tal agitação, juntam-se as imundícies dos grãos no meio da peneira, mas tal movimento não tem a ver com o movimento do céu, que é em torno do próprio centro fixo e estável. Porém, para que a experiência seja tal que possa acomodar-se ao propósito, é preciso que vós, mantendo o centro da peneira sempre no mesmo lugar, façais girar em torno dele velozmente a peneira e, enquanto ela está dessa maneira girando, atirai dentro pedriscos ou pedacinhos de terra e observai aquilo que eles farão; que sem mais outro vê-los-eis retirarem-se para a circunferência, até que toquem a borda da peneira e aqui parar-se-ão. Ora, para que a experiência da peneira tenha valor [542] junto de vós, mudai de opinião e dizei que por necessidade é preciso que a Terra esteja afastada do centro. Antes, se considerardes mais precisamente o efeito dos pedriscos na experiência produzida por vós mesmos, percebereis que o retirarem-se eles para o centro da peneira não é outra coisa que o conduzir-se para a circunferência do movimento que se faz, pois que o centro da peneira caminha pela circunferência desse movimento circular. Poderia também dizer-vos que o efeito que vós atribuís à peneira segue-se quando ela se mova, mas não quando estivesse parada; ora, a peneira que seguramente sabemos que se move é aquela que está compreendida dentro do orbe de Saturno, ou seja, dos orbes dos planetas, no centro dos quais não está de qualquer modo a Terra, mas o Sol; portanto, ou o exemplo não é verdadeiro, ou não vem ao propósito, ou o Sol é mais grave que a Terra.

Seguem em vosso escrito os argumentos com os quais pretendeis poder demonstrar a estabilidade da Terra e despojá-la de todos os movimentos que lhe são atribuídos por Copérnico, isto é, o diurno sobre si mesma e os outros dois mais, um em torno do Sol pela eclíptica e o outro, também sobre si mesma, mas quase contrário ao diurno; e ainda que o movimento anual em torno do Sol seja abandonado, sempre que tenhais 
demonstrado que a Terra está colocada no centro do universo, todavia (creio que para abundar em cautela) produzis também outras razões contra ele.

Quanto ao movimento diurno, ou seja, o movimento sobre si mesma em 24, horas de ocidente para oriente, das muitas razões e experiências que foram formuladas por Aristóteles, Ptolomeu, Tycho e outros, vós passais por elas bastante ligeiramente acenando para apenas duas, isto é, aquela usadíssima dos corpos graves que caem perpendicularmente sobre a superfície da Terra e a outra dos projéteis, os quais sem qualquer diferença movem-se por espaços iguais tanto para levante quanto para poente e tanto para o sul quanto para o norte; e passais por elas tão brevemente, creio, talvez pela muita evidência e [543] necessidade com as quais parece-vos que elas convençam. Mas eu, sejam estas, sejam as outras muito bem conhecidas e examinadas por Copérnico e bastante mais curiosamente por mim, considero em todas ou não existir nada que possa concluir nem pela parte afirmativa nem pela parte negativa, ou, se em algum [argumento] existe alguma ilação, esta é favorável à opinião copernicana; mas afirmo mais, existirem outras experiências não observadas até aqui por alguém, as quais (ficando dentro dos termos dos discursos humanos e naturais) necessariamente convencem da firmeza do sistema copernicano. Mas todas essas coisas, enquanto necessitadas para sua explicação de mais longos argumentos, reservemo-las para outro momento; e enquanto isso, para responder com quanto basta às coisas tocadas por vós, torno a replicar que vós, juntamente com todos aqueles outros, por ter-vos primeiramente impresso firmemente na mente a estabilidade da Terra, incorreis depois em dois erros gravíssimos: um é o ficar girando sempre entre equívocos, supondo como conhecido o que está em questão; e o outro é que, sobrevindo-vos experiências que se podem fazer, através das quais pudésseis chegar à luz do verdadeiro, sem de outro modo fazê-las, ponde-as como feitas e trazei-as como respondendo a favor de vossa conclusão. Eu, com a maior brevidade que puder, procurarei tornar-vos palpáveis esses dois erros; e outra vez podereis ver bastante claramente tratado esse ponto, com as respostas a todas as objeções que à primeira vista parecem ter alguma probabilidade, sem que tenham a mínima.

Vós, com Aristóteles e outros, dizeis: se a Terra girasse sobre si mesma em 24 horas, as pedras e os outros corpos graves que caem do alto para baixo, do cimo, por exemplo, de uma torre alta, não acabariam por percutir na Terra ao pé da torre; visto que, no tempo em que a pedra se mantém no ar descendo em direção ao centro da Terra, essa Terra, procedendo com suma velocidade para levante e levando consigo o pé da torre, acabaria por necessidade deixando para trás a pedra por tanto espaço quanto o da vertigem da Terra, no mesmo tempo, tivesse corrido para frente, o que seriam muitas centenas de braças. Esse argumento eles confirmam posteriormente com um exemplo tomado de uma outra experiência, dizendo que isso se vê manifestamente em um 
navio, no qual, quando ele está parado no porto, deixa-se da sumidade do mastro cair livremente uma pedra, esta, descendo perpendicularmente, vai percutir ao pé do mastro e precisamente naquele ponto que [544] fica a prumo por debaixo do lugar de onde se deixou cair a pedra; efeito que não acontece (supõem eles) quando o navio se move em curso veloz; com efeito, no tempo que a pedra consuma para vir de cima para baixo e no qual ela, posta em liberdade, descende perpendicularmente, escorrendo o navio para frente, deixa por muitas braças a pedra para a popa distante do pé do mastro; efeito esse que deveria seguir-se para a pedra que cai do alto da torre, quando a Terra circulasse com tanta velocidade. Este é o argumento, no qual percebo muito claramente ambos os erros acerca dos quais falei.

Com efeito, que a pedra cadente do alto da torre mova-se por linha reta e perpendicular à superfície terrestre, nem Aristóteles, nem vós recolheis de outra coisa, nem podeis recolher, que do ver como, na sua descida, ela vem, por assim dizer, lambendo a superfície da torre, levantada perpendicularmente sobre a Terra; de modo que se percebe que a linha descrita pela pedra é também ela reta e perpendicular. Mas eu vos digo que dessa aparência não se pode de modo algum inferir isso, se não se supõe que a Terra esteja imóvel enquanto a pedra desce, que é então o quesito que se procura; porque, se eu disser com Copérnico que a Terra gira e, em conseqüência, leva consigo a torre e também nós que observamos o efeito da pedra, diremos que a pedra move-se com um movimento composto do movimento circular universal diurno para levante e do outro reto acidental para o seu todo, dos quais resulta um inclinado para oriente; dos quais aquele que é comum a mim, à pedra e à torre fica para mim, nesse caso, imperceptível e como se não existisse e somente fica observável o outro, que a torre e eu não temos, a saber, a aproximação à Terra. Eis, portanto, evidente o equívoco, se, entretanto, eu me tiver explicado suficientemente. E acrescento-vos mais, que assim como vós, com Aristóteles, argumentando das partes para o todo, dizeis que, vendo-se as partes da Terra moverem-se natural e retamente para baixo, tal se podia inferir ser a inclinação natural de toda a Terra, ou seja, de procurar o centro e nele, tendo-o atingido, ter-se parado; assim também eu muito melhor, argumentando do todo para as partes, direi que, sendo uma inclinação e operação natural do globo terrestre [545] o circular em 24 horas em torno do seu centro, essa é ainda a inclinação das partes e que, por isso, por sua natureza, devem circundar o centro da Terra em 24 horas e que essa é a sua ação inata, própria e naturalíssima, à qual acrescenta-se (embora acidentalmente) a outra de descer, quando por alguma violência elas tivessem sido separadas do seu todo; e discorro tanto mais perfeitamente que Aristóteles e vós quando atribuís como movimento natural da Terra aquele do qual ela nem jamais se moveu nem eternamente mover-se-á, digo, o movimento reto para o centro; mas eu, para ela e para todas as suas partes, faço natural um movimento perfeitíssimo que lhes convém perfeitamente e que é por elas exercitado. 
Quanto ao outro erro, que é o de produzir experiências como feitas e favoráveis a vossa necessidade sem tê-las jamais nem feito nem observado, primeiro, se vós e Tycho quisésseis sinceramente confessar a verdade, diríeis jamais ter experimentado (e principalmente nos países próximos ao pólo, onde o efeito seria, tanto quanto dizeis, mais conspícuo) se acontece ou não acontece alguma diferença daquelas que vos parece que devessem aparecer no atirar com as artilharias ora para levante ora para poente, ora para setentrião ora para austral; e para assim crer, ou antes, para estar certo, move-me o ver trazer como certas e claras outras experiências bastante mais fáceis de fazer-se e de observar-se, das quais depois tenho tanta certeza que não as haveis feito quanto que para quem as faz o efeito acontece ao contrário daquilo que, com tanta confiança, eles diziam. E uma dessas experiências é exatamente a da pedra que cai da sumidade do mastro do navio, a qual vai sempre terminar batendo no mesmo lugar, tanto quando o navio está parado quanto quando ele caminha velozmente, e não vai, como eles acreditavam (afastando-se o navio enquanto a pedra vem pelo ar para baixo) bater longe do pé em direção da popa; na qual eu tenho sido duplamente melhor filósofo do que eles, porque eles, ao dizer aquilo que é contrário ao efeito, acrescentaram também a mentira, dizendo terem visto isso pela experiência, antes da qual a razão natural tinha-me muito firmemente persuadido de que o efeito deveria acontecer exatamente como acontece: nem [546] foi-me uma coisa difícil conhecer o engano deles, os quais, imaginando-se alguém que, estando parado o navio, fosse ao cimo do mastro e, assim, estando o todo em repouso, dali deixasse cair uma pedra, não advertem depois que, quando o navio estava em movimento, a pedra não partia mais do repouso, visto que o mastro e o homem no mastro e a sua mão e também a pedra moviam-se com a mesma velocidade que todo o navio; e mesmo assim tenho constantemente entre as mãos engenhos tão materiais que não se lhes pode entrar na cabeça que, tendo aquele que está no alto do mastro o braço parado, a pedra não parta do repouso. Digo-vos, portanto, Sr. Ingoli, que, enquanto o navio está em curso, com igual ímpeto move-se também aquela pedra, cujo ímpeto não se perde porque aquele que a segurava abra a mão e a deixe em liberdade, mas antes nela se conserva indelevelmente, de modo que esse [ímpeto] é suficiente para fazer a pedra seguir o navio; e pela própria gravidade, não mais impedida por aquele [que a segurava], vem para baixo, compondo com ambos um só movimento transversal e inclinado (e talvez mesmo circular) para onde caminha o navio; e, assim, vem cair naquele mesmo ponto do navio em que caía quando o todo estava em repouso. A partir disso podereis compreender como as mesmas experiências produzidas pelos adversários contra Copérnico estão bastante mais a favor dele do que a favor deles; porque, se o movimento comunicado pelo curso do navio à pedra, o qual é para essa pedra indubitavelmente acidental, nela todavia de tal modo se conserva que se percebe precisamente o mesmo efeito tanto no repouso quanto no movimento do 
navio, que dúvida deverá restar de que a pedra, levada sobre a sumidade da torre com a mesma velocidade que todo o globo terrestre, conserve a mesma [velocidade] quando vem depois para baixo? A mesma, digo, a qual não lhe é, como aquela do navio, acidental mas é a sua inclinação natural primária e co-eterna.

Quanto ao movimento dos projéteis das artilharias, ainda que eu não tenha feito as experiências, não tenho dúvida alguma de que não deve acontecer exatamente aquilo que diz Tycho e vós com ele, ou seja, que não se verá diferença alguma e que os tiros resultarão sempre os mesmos, feitos para [547] qualquer parte que se queira do mundo; mas acrescento ainda (aquilo que Tycho não entendeu) que isso acontecerá porque assim é necessário que aconteça, mova-se ou esteja parada a Terra, nem qualquer diferença imaginável pode perceber-se, como entendereis com evidentes razões a seu tempo. E, entrementes, para remover estas e todas as outras dificuldades desse gênero, como são o voar dos pássaros e como possam empreender um tal movimento, como também as nuvens suspensas no ar, as quais, entretanto, não escorrem sempre para o ocidente, como parece a vós outros que devesse acontecer quando a Terra se movesse; para remover-vos, digo, todas essas aparentes dificuldades, digo-vos que enquanto a água, a terra e o ar, que lhes é o ambiente, façam em concordância as mesmas coisas, ou seja, ou movam-se conjuntamente ou estejam conjuntamente paradas, [então] representar-se-ão necessariamente todas as mesmas aparências ad unguem tanto em um como no outro estado; todas, digo, aquelas que dizem respeito aos referidos movimentos dos graves cadentes, dos projéteis para o alto ou lateralmente para esta ou aquela parte, do voar dos pássaros para levante ou poente, dos movimentos de nuvens etc. Mas precavei-vos, Senhor Ingoli, de algum outro efeito que, no ar, na água, na terra ou ainda no céu, devesse ser percebido e fosse potente para fazer-nos chegar à cognição certa do fato; precavei-vos, digo, pois que tenho grande opinião de que ele acontecesse a vosso manifesto desfavor. Quanto aos referidos, tomai somente esta experiência, apropriadíssima para encaminhar-vos pelo reto caminho, ao mostrar-vos, como já disse, ser impossível retirar deles nada que sirva um jota para desvelar essa dúvida.

No maior compartimento existente sob a coberta de um grande navio, fechaivos com algum amigo, e fazei que aí existam moscas, borboletas e semelhantes animaizinhos voadores; tomai também um grande recipiente com água, contendo pequenos peixes; acomodai ainda ao alto algum vaso que vá gotejando em um outro, de boca estreita, colocado por baixo; e, estando em repouso o navio, observai diligentemente como aqueles animaizinhos voadores com igual velocidade vão para todas as partes do ambiente; ver-se-ão os peixes nadar indiferentemente para qualquer parte do vaso; as gotas cadentes entrarem todas no vaso posto embaixo; e vós, lançando uma fruta para o amigo, não a deveis lançar com mais força para esta que para aquela parte, quando [548] as distâncias sejam iguais; e saltando, como se diz, com os pés juntos, transporíeis 
espaços iguais para todas as partes. Assegurai-vos de ter todas essas coisas, e fazei mover o navio com quanta velocidade desejardes; porque (sempre que o movimento seja uniforme e não flutuante de lá para cá) não reconhecereis uma mínima mudança em todas as mencionadas coisas, nem de nenhuma delas, nem mesmo de algo que esteja em vós mesmos, podereis assegurar-vos se o navio caminha ou está parado: saltando, percorreríeis no tablado os mesmos espaços que antes, nem daríeis saltos maiores para a popa que para a proa, porque o navio se move muito velozmente, ainda que, no tempo durante o qual estejais no ar, o tablado subjacente deslize para a parte contrária ao vosso salto; e lançando uma fruta ao companheiro, não será necessário lançá-la com mais força para alcançá-lo, se ele estiver para a proa e vós para a popa, que se estivésseis colocados ao contrário; as gotas continuarão a cair como antes no recipiente inferior, sem que nenhuma caia em direção à popa, ainda que, enquanto a gota está no ar, o navio navegue muitos palmos; os peixes na sua água nadarão sem maior esforço tanto para a parte precedente quanto para a parte subseqüente do vaso, e com a mesma facilidade chegarão ao alimento colocado em qualquer lugar da borda do recipiente; e finalmente as borboletas e moscas continuarão seus vôos indiferentemente para todas as partes, e nunca acontecerá que se concentrem na parte endereçada para a popa, como se estivessem cansadas de acompanhar o curso veloz do navio, do qual por muito tempo elas estariam separadas, isto é, enquanto ficam suspensas no ar; e se queimando alguma lágrima de incenso produzísseis um pouco de fumaça, veríeis que ela se eleva para o alto e como uma pequena nuvem se mantém, movendo-se indiferentemente não mais para esta do que para aquela parte. E se de todos esses efeitos me perguntardes a razão, responder-vos-ei por ora: "porque o movimento universal do navio, sendo comunicado ao navio e a todas as coisas que nele estão contidas, e não sendo contrário à inclinação natural delas, nelas indelevelmente se conserva"; em outra oportunidade, ouvireis respostas particulares e difusamente explicadas. Ora, quando tiverdes visto todas essas experiências, e como esses movimentos, ainda que acidentais [549] e adventícios, mostram-se exatamente iguais tanto quando o navio se mova quanto se ele está parado, não deixareis toda dúvida de que o mesmo deva acontecer a respeito do globo terrestre, sempre que o ar acompanhe o globo? E tanto mais, quanto aquele movimento universal, que no navio é acidental, nós o pomos, na Terra e nas coisas terrestres, como seu natural e próprio. Acrescentai mais, que, no navio, ainda que cem vezes o tenhamos posto em movimento e o façamos estar parado, nem por isso pudemos aprender a conhecer das coisas internas aquilo que ele faz: como será possível conhecer isso na Terra, a qual a temos tido sempre em um mesmo estado?

Passo aos argumentos que vós, juntamente com Tycho, trazeis para a destruição do movimento anual, nos quais, mais claramente que jamais, percebo que nem vós nem ele chegastes a formar-vos uma idéia perfeita da constituição do mundo de 
Copérnico e das aparências e acidentes que dessa se seguem e que aos nossos olhos devem demonstrar-se, mas, confundindo os conceitos antigos e habituais com as novas posições, continuais ainda a discorrer cometendo equívocos.

Vós trazeis quatro argumentos contra o movimento anual sob o zodíaco. O primeiro é o de não verdes vós variar em nada as latitudes ortivas e ocíduas das estrelas fixas, as quais afirmais que, com o dito movimento, deverão variar notavelmente a cada oito dias, já que, movendo-se a Terra conjuntamente com o horizonte de austral para boreal com movimento que de 8 em 8 dias se faz sensível, e estando (como afirma Copérnico) as estrelas fixas imóveis, é necessário que, no mesmo tempo, variem notavelmente suas latitudes ortivas e ocíduas; coisa que dizeis não se ver; onde etc. Este argumento é em muitos itens ineficaz.

E, primeiro, eu não sei o quanto eu deva acreditar que vós ou Tycho tenhais feito diligentes observações nas latitudes ortivas e ocíduas das estrelas fixas, e duvido que a imaginada estabilidade da Terra vos tenha persuadido da imutabilidade daquelas latitudes muito antes que a observada imutabilidade vos tenha assegurado da estabilidade terrestre. Assegura-me, secundariamente, de tal opinião a incerteza dessa [550] observação, dificílima, se não impossível, de poder ser feita com a exatidão que seria requerida, seja porque são pouquíssimas as estrelas que se percebem no horizonte, seja porque em tal lugar as refrações impedem enormemente de vê-las em seu lugar verdadeiro e real; e o impedimento é tanto que muitas vezes ocorreu-me ver ambas as luminárias sobre o horizonte e a Lua já eclipsada, acidente que nos deixa certos ainda de existir verdadeiramente uma estrela sob o horizonte, quando ela se nos mostra não pouco elevada, de modo que seu nascer e pôr-se pode tornar-se enganoso por tal alteração que produz bastante maior desvio que aquela mínima diferença que se pudesse notar mediante o movimento anual da Terra. Terceiro, vós afirmais que, quando o movimento fosse da Terra, movendo-se ela juntamente com o horizonte, a mutação deveria, a cada oito ou dez dias, ser notável e, por isso, ser percebida como tal nas estrelas fixas. Ao que vos respondo ser tal movimento notável e notabilíssimo onde é necessário que ele seja tal, mas não onde ele tal não deve mostrar-se. E não nos parece ele notabilíssimo no Sol, variando as suas latitudes horizontais em cinqüenta e sessenta graus? Eu quero com um exemplo apropriadíssimo agilizar-vos a inteira inteligência desse negócio: e esse será o de trazer-vos à memória um acontecimento que acredito tenha sido por vós muitas vezes observado ao ir de barca de Pádua a Veneza; onde vós, observando os mastros plantados ao longo das margens do Brenta, e outros mais distantes, e outros e outros ainda mais e mais distantes, até as cordilheiras dos Alpes, pareceu-vos as mais vizinhas correrem velozmente contra o movimento da barca, outras, um tanto mais distantes, moverem-se também contra o vosso movimento, mas mais lentamente que as mais próximas, mas, em comparação com aquelas e estas, outras 
mais distantes pareceram-vos mover-se contrariamente e seguir o curso da barca e, finalmente, as afastadíssimas, como se fossem sequazes da barca, demonstrarem-se a vós sempre no mesmo aspecto; precisamente daquele modo que faz a Lua, a qual vos parece mover-se à noite sobre as cumieiras dos tetos quando caminhais pela estrada, embora fique verdadeiramente para trás, e isso por seu grande distanciamento. A barca do nosso horizonte deixa, portanto, o Sol, seu vizinho, bastante para trás, enquanto ultrapassa o diâmetro do orbe magno; mas, em [551] comparação com ele, as estrelas afastadíssimas mostram-se para nós totalmente como nossas sequazes. Não desejo que coloqueis a distância das fixas a mais de 3 oo diâmetros do orbe magno (ainda que sem nenhum escrúpulo se pudesse pôr a mais de mil). Ora, imaginai alguém que para um mesmo sinal, que esteja a 300 passos de distância, traçe duas linhas separadas uma da outra um só passo, e tentai depois se, não olhando outra coisa que as linhas, podeis aperceber-vos sensivelmente de que elas não são paralelas entre si; pois que, sem outro, a sua imperceptível diferença remover-vos-á toda dificuldade. Uma diferença similar e, por outros acidentes, bastante menor é aquela que vós desejais nas amplitudes ortivas das fixas, as quais, como são imperceptíveis, não mais vos deveriam dar preocupação. Mas acerca disso, muito mais em outra oportunidade.

Passo a vossa segunda razão tomada das alturas polares, as quais, quando a Terra no movimento anual se aproximasse e se afastasse do setentrião por um espaço tão grande quanto é o inteiro diâmetro do orbe magno, que é duas vezes quanto é a distância da Terra ao Sol, parece-vos uma coisa impossível que não devessem alterar-se, levantando-se e fazendo-se maiores, quando a Terra se aproxima de setentrião, e menores quando ela se encontra em austral: conseqüência que vós fortificais com a experiência que nos mostra que ao mover-se um homem sobre a Terra somente 60 milhas para boreal, o pólo se lhe eleva um grau; do que vosso argumento infere depois que levado esse mesmo homem também para boreal pelo globo terrestre não somente as mesmas 60 milhas mas muitas centenas de milhares, uma variação bastante maior do que a apresentada dever-vos-ia ser percebida; nada menos do que nenhuma sensível é observada; do que vós inferis a estabilidade dessa Terra. Ora, eis aí, Senhor Ingoli, um testemunho bastante claro daquilo que vos disse acima, que vós, por não ter bem apreendido a hipótese copernicana e por não saber livrar-se dos antigos conceitos impressos na mente, confundis o céu e a Terra e pronunciais uma grande bobagem.

Digo-vos, portanto, que não só a aproximação e o distanciamento de um diâmetro do orbe magno ao setentrião não deve fazer mudança alguma nas alturas polares, mas que nem mesmo faria diferença a [552] transposição de 100 ou de mil de tais diâmetros; e muito me admiro de que vós, e muito mais de que Tycho, tão puerilmente vos tenhais enganado. Mas procuremos a causa do engano. Tendo aprendido em Sacrobosco que a Terra está imóvel no centro da esfera estelar e tendo acreditado que tal esfera é 
aquela que faz a conversão diurna, nela estabelecestes o eixo de tal conversão, e marcados os pólos e desenhada a equatorial, círculo máximo produzido pelo ponto do orbe estelar que está igualmente distante de ambos os pólos; e essas coisas, figuradas por vós realmente no céu, haveis transferido para a Terra, entendendo nessa os pólos e o eixo e o equatorial como subjacente perpendicularmente a aqueles do céu. Copérnico, ao contrário, fazendo o firmamento ficar parado e atribuindo o movimento diurno à Terra, tira do céu o eixo, o pólo e o círculo equatorial e ainda todos os outros, e atribui tudo à Terra, porque tais coisas não se encontram em uma esfera que não gire sobre si mesma. Éverdade que nós com a imaginação podemos transferi-los para o céu e chamar eixo do mundo aquele da Terra prolongado até a esfera estelar, e pólos aqueles dois pontos que nela marcar o eixo, e equador aquele círculo máximo que será feito pelo plano de nosso equador terrestre estendido até lá. Ora, alguém que na Terra esteja sobre o círculo máximo da rotação diurna, isto é, sobre o equador, terá seu horizonte que passará por ambos os pólos; e se caminhando na superfície terrestre em direção a um dos pólos afastar-se do equador, tanto quanto ele se afastar, tanto inclinar-se-á o seu horizonte e, em conseqüência, levantar-se-á o dito pólo; mas se ele se detiver em algum sítio e a Terra continuar a girar em torno ao mesmo eixo e em torno dos mesmos pólos, transposta essa Terra em qualquer lugar que se queira do mundo, então nem o equador, nem o horizonte, nem o eixo, nem os pólos com respeito a esse homem farão uma mínima mutação. E para especificar-vos com um exemplo apropriadíssimo o erro de Tycho e vosso, saibai que vosso equívoco é exatamente aquele que seria de alguém que, estando na poupa da galera, olhasse pela viseira do quadrante a sumidade da antena e a encontrasse, por exemplo, elevada 30 graus sobre o horizonte de seu olho e caminhando depois pela ponte em direção ao mastro 20 ou 30 passos, voltasse a observálo, e encontrasse que se elevou mais 10 graus, e fosse então tão [553] simplório que imaginasse que o mesmo deveria acontecer-lhe se, ao invés de mover-se ele mesmo pela galera aproximando-se do mastro, toda a galera se movesse para a mesma parte, ficando ele sempre na popa, e não entendesse que, quando fosse a galera a mover-se, não só os 20 ou 30 passos mas outras tantas milhas e milhares de milhas, a elevação da antena do mastro ficaria sempre a mesma. Vós, Senhor Ingoli, ao fazer mover a Terra em direção a boreal, em conformidade com Copérnico, esqueceis, portanto, que os pólos de seu movimento diurno estão realmente na Terra, e imaginariamente no céu, e não considerais que, retirando-se a Terra em direção a boreal, leva consigo nós, o nosso horizonte e os seus pólos reais, cujo movimento move também os imaginados no céu; e porque esse movimento é comum a nós e aos pólos, por isso não produz alteração alguma, e é como se ele não fosse. Auxiliemo-nos quanto é possível. Vós devíeis dizer que com tal movimento mudava-se não a elevação do pólo, mas a elevação de alguma estrela fixa, como, por exemplo, da Ursa Menor que está ali perto e acrescentar 
depois que, ao não se ver isso, disso retirais argumento a favor da estabilidade da Terra. Mas a isso já respondeu Copérnico, dizendo que com respeito ao imenso distanciamento das fixas, tal mutação permanece insensível. Mas eu, além disso, acrescento outras coisas mais, as quais ouvireis a seu tempo; mas entretanto digo-vos que não tendo vós por vós mesmos feito tais observações, não deveis prestar tão firme fé a Tycho e aos seus instrumentos, inaptos porventura a poder distinguir tais minúcias, qua talvez com outros instrumentos, e muito maiores e muito mais perfeitos e bastante diferentes, poderão um dia ser compreendidos.

Se tiverdes entendido o que eu disse até aqui, podereis por vós mesmos compreender a falácia do vosso terceiro argumento, tomado da desigualdade dos dias, cuja falácia tem raiz nos mesmos equívocos. O equador, torno a responder, os horizontes, o zênite, o eixo, os pólos e a conversão diurna, pela qual se descrevem os arcos diurnos e noturnos, isto é, os paralelos ao equador, são todas coisas da Terra, nem o firmamento nem suas estrelas têm algo a ver com isso, como se neste caso eles não existissem na natureza; o movimento anual [544] e a manutenção do equador e de seu eixo com a mesma inclinação e direção com respeito ao Zodíaco, ou seja, ao círculo do movimento anual, fazem que as irradiações dos raios solares (que é o que produz o dia) cortem aqueles paralelos ora todos em partes iguais (que é quando o seu término passa pelos pólos do equador), ora em partes desiguais (com exceção do equador que, por ser círculo máximo, sempre vem cortado igualmente), deixando maiores ora os arcos diurnos ora os noturnos; os diurnos quando a Terra está em direção a austral, os noturnos quando está em direção a boreal. Mas estou certo de que estas são matérias de tal abstração que é necessária outra explicação mais longa para fazer-se entender; mas a ouvireis a seu tempo.

O quarto argumento é um puro arbítrio de Tycho e proferido sobre algo que ele, ao que me parece, jamais observou, nem pôde observar, digo, do movimento dos cometas postos em oposição ao Sol, dos quais, se é verdade, eu estimo muito verdadeiro, que estendem a cauda em oposição ao Sol, é impossível que algum se mostre em oposição ao Sol, já que em tal caso a cauda ficaria invisível. Além disso, que segurança teve jamais Tycho do movimento do próprio cometa, a partir do qual ele pudesse francamente asseverar que aquele, misturado ao movimento da Terra, tenha que produzir outra aparência do que aquela que se viu? Ele imaginou muito inverossimilmente uma teoria cometária, e arvorando-se em árbitro e regulador de todos os afazeres astronômicos, de modo que só são verdadeiras e justas aquelas coisas que respondem a suas observações ou fantasias, do não ver aparências no cometa que pudessem satisfazer à hipótese copernicana e ao seu vão capricho, quis antes negar e refutar aquela do que abandonar isso. 
Resta-me considerar as objeções que Tycho e vós fazeis contra o terceiro movimento anual em torno do próprio centro, em sentido oposto ao anual pelo orbe magno; onde dizeis primeiramente que, retirado aquele do orbe magno, remove-se também esse terceiro; o que vos seja por ora concedido; mas aquele ainda não foi removido, portanto, o terceiro permanece igualmente. Como segunda objeção pondes como impossível que o eixo da Terra se mova, ou possa mover-se, com tanta correspondência ao [555] movimento anual do centro, que é como se estivesse parado. Mas eu vos digo, não apenas isso não ser impossível, mas ser necessário e que um tal efeito se vê evidentemente seguir-se em todo corpo que esteja livremente suspenso, como a muitos fiz ver; e vós mesmos podeis obter a prova pondo uma bola de cortiça em um copo de água, o qual se o segurais na mão e, com o braço esticado, derdes uma volta sobre vossos pés, vereis a dita bola girar sobre si mesma com um movimento contrário ao vosso e terminar uma conversão no mesmo tempo em que haveis terminado a vossa. Isso vereis seguirse por necessidade; de outro modo entendereis que a bola verdadeiramente não gira nada, ao contrário, que ela retém sempre a mesma direção com qualquer ponto estável e exterior à vossa circulação, que é assim a mesma propriedade que Copérnico atribui à Terra. Isso acaba satisfazendo também o terceiro argumento, muito similar, se não igual ao segundo, pois que vós replicais não ser possível que em um mesmo corpo o centro e o eixo se movam com movimentos contrários, coisa que não somente não é impossível (representando o movimento tal qual Copérnico o representa), mas é necessária. Nem dizeis que a dificuldade se faz maior com o acréscimo também do movimento diurno, quase como que tivésseis por grande absurdo que um mesmo móvel, no mesmo tempo, mova-se com tantos movimentos diferentes; porque eu não considero absurdo algum que se mova não apenas com 3, mas com 10 e 100, como ouvireis em outra oportunidade, ainda que, por fim, do composto de todos não resulte outro que um só movimento, de modo que, se o corpo móvel deixasse com algum de seus pontos o vestígio de todos os seus movimentos, não deixaria outra coisa que uma simples linha.

Passo aos três argumentos físicos adotados por vós para provar o repouso da Terra, o primeiro dos quais (posto de lado os ornamentos que lhe fazeis) é em substância o seguinte. Os corpos graves são menos aptos ao movimento que os não graves, pois assim nos mostra a experiência; mas de todos os corpos conhecidos por nós a Terra é gravíssima; portanto, é preciso dizer que a natureza não lhe atribuiu tantos movimentos, e principalmente o diurno, tão veloz que em um minuto de hora deveria transpor 19 milhas. [556] Conviria discorrer longamente se eu quisesse considerar todas as falácias que existem nesse e em argumentos semelhantes: tratarei do que basta para mostrar a nulidade de eficácia. 
E primeiramente, aos meus olhos se apresenta totalmente o contrário que aos vossos. Vós vedes os corpos graves serem renitentíssimos a todos os movimentos, tanto naturais como violentos, e os leves serem ainda mais dispostos; e eu vejo (começando pelos movimentos naturais) mais veloz e prontamente mover-se uma rolha que uma pena, mais um pedaço de madeira que uma rolha, mais que a madeira uma pedra, e mais do que esta um pedaço de chumbo. $\mathrm{O}$ mesmo vejo nos movimentos violentos e vejo que, colocando em uma peça de artilharia balas de diferentes materiais e atirando-as com o mesmo fogo, muito mais velozmente e por mais longo tempo, mover-se uma bala de chumbo que uma de madeira, e bastante menos um chumaço de palha ou de estopa; vejo que se de fios iguais forem suspensas bolas de cortiça, de madeira e de chumbo e a todas se conferir igualmente um início de movimento, aquela de cortiça em brevíssimo tempo parará, bem mais durará movendo-se daqui para ali a outra de madeira, e mais aquela de chumbo; e, ao contrário, se no fundo de um vaso repleto de água atar-se um fio o mais próximo possível da profundidade da água e ao qual, na outra ponta, seja atada uma palha ou outro corpo leve e que, afastado da perpendicular, deixe-se em liberdade, este, chegando à perpendicular, imediatamente parará, nem fará reciprocação alguma, como fazem os pêndulos graves na mesma água e mais no ar. Vejo os ceramistas e os torneiros de pratos de estanho acrescentar a seus aparatos rodas de madeira pesadíssima, para que mais longamente retenham o ímpeto que lhe foi conferido; e o mesmo se faz com os volantes em muitas outras máquinas. Vejo que o ar de um cômodo, depois de ter sido agitado, pára imediatamente, mas que a água de um dique não faz assim, que, parando o agitador, por longo tempo retém o ímpeto e agitase. Teria desejado ouvir quais são as experiências (das quais vós não acrescentais nem mesmo uma) que vos persuadiram do contrário.

Secundariamente, de onde retirastes vós que o globo terrestre seja tão pesado? $\mathrm{Eu}$, de minha parte, ou não sei o que seja a gravidade, ou o globo terrestre não é nem grave nem leve, como também todos os outros globos do [557] universo. Gravidade, para mim (e creio que segundo a natureza), é aquela inclinação inata pela qual um corpo resiste a ser removido de seu lugar natural, e pela qual, quando forçadamente ele tinha sido removido, espontaneamente para aí retorna: e assim, um balde de água, levado para o alto e depois deixado em liberdade, retorna ao mar; mas quem dirá que a própria água no mar seja grave, pois que, estando ela em liberdade, ainda assim nele se move? Vós, ao dizer que os corpos não graves estão mais aptos ao movimento que os graves, dizeis, ao meu parecer, uma proposição diametralmente oposta à verdade, porque a verdade é que os corpos não graves são os mais ineptos de todos os corpos. De modo que, não podendo o movimento fazer-se a não ser em algum meio, nem tampouco conhecer gravidade e leveza a não ser em relação ao meio, os corpos não graves são somente aqueles que são em espécie igualmente graves ou leves com o meio no qual se 
encontram. Assim, um corpo que na água não seja nem grave nem leve será aquele que em espécie terá igual gravidade que a água; mas um tal corpo não se moverá em absoluto com movimento natural naquele meio, não sendo nele nem grave nem leve; nem tampouco se moverá com movimento violento, a não ser enquanto estiver unido ao movente, mas, abandonado por aquele, rapidamente cessará de mover-se; donde, um corpo que no mesmo meio seja grave e que nele desça naturalmente, mover-se-á nele conservando a virtude que lhe foi impressa pelo arremessador, e um e outro fará tanto mais, quanto mais grave for.

Aquilo que acrescentais ao final segue-se de mostrar o domínio que em vós tem o afeto sobre a razão, enquanto apontais como um gravíssimo absurdo o querer que a Terra gire sobre si mesma em 24, horas e parece-vos ser esta uma velocidade muito exorbitante, e contrariamente laudais e concedeis como coisa facílima o fazer moverem-se cem mil corpos maiores que a Terra com velocidade cem mil vezes maior que aquela; e tais são as estrelas fixas e a revolução diurna atribuída a sua esfera. Mas se vós, para persistir na vossa opinião, ou, para dizer melhor, na vossa primeira afirmação, vos limitais a admitir semelhantes extravagâncias, que esperança deixaríeis a quem quer que seja de jamais poder com todas [558] as evidências do mundo persuadir-vos de uma palpabilíssima verdade, a qual tenha sido alguma vez negada por vós?

$\mathrm{O}$ vosso segundo argumento é tomado de uma proposição física que afirma que para cada corpo natural um só, e não mais, pode ser o seu movimento natural; e sendo o movimento natural da Terra o mover-se para o centro, não lhe poderão de modo algum convir naturalmente tantos movimentos circulares; e não lhe sendo naturais, como poderia ela se mover por tão longo tempo? A essa objeção seria uma resposta bastante competente aquilo que responderíeis a alguém que vos interrogasse e dissesse: dizeis, Senhor Ingoli, que o movimento natural do globo terrestre é o mover-se para o centro; mas como ele lhe pode ser natural, se ela jamais se moveu por tal movimento, nem jamais se moverá? Para os vossos mesmos filósofos o movimento circular não tem movimento que lhe seja contrário, mas o repouso é contrário a todo movimento. Ora, por que vos dá tão grande preocupação que a Terra dure tanto movendo-se circularmente, que não é movimento contrário àquele que chamais natural para ela, e não vos preocupa minimamente o dizer que ela tenha estado eternamente ou deva estar imóvel, contra a sua inclinação natural, que é a de se mover? Quanto seria menos mal dizer que natural para a Terra é o estar parada, pois que, segundo vós, sempre esteve assim! $\mathrm{O}$ que afirmei responderia muito abundantemente à vossa objeção; mas eu acrescento mais, e digo-vos que, se os corpos naturais devem por natureza mover-se com algum movimento, este não pode ser senão o movimento circular, nem é possível que a natureza tenha dado propensão a algum dos seus corpos integrais de mover-se com movimento reto. Desta proposição tenho muitas confirmações, mas é suficiente por ora 
uma só, a qual é a seguinte. Suponho que as partes do universo estão constituídas em ótima disposição, de modo que nenhuma esteja fora de seu lugar, que é o mesmo que dizer que a natureza e Deus têm perfeitamente ordenada a sua construção. Isso posto, é impossível que alguma dessas partes tenha por natureza que se mover com movimento reto ou de outro diferente do circular, porque aquilo que se move com movimento reto muda de lugar e, se o muda naturalmente, portanto, ele estava antes em um lugar [559] que era contrário a sua natureza, o que é contrário à suposição. Portanto, se as partes do mundo são bem ordenadas, o movimento reto é supérfluo e não natural, e só poderá ter uso quando algum corpo fosse removido por violência do seu lugar natural, pois então talvez retornasse a ele por linha reta, pois assim nos parece fazer uma parte da Terra separada de seu todo. Afirmei nos parece, porque não estou longe de acreditar que nem mesmo para semelhante efeito a natureza se sirva do movimento reto. Tais inconvenientes não se seguem no movimento circular, o qual, sem desordenar em nada a ótima constituição das partes, pode ser de uso na natureza, porque aquilo que gira sobre si mesmo não muda de lugar, e aquilo que vai por uma circunferência não impede os outros e vai sempre na direção de onde partiu, de modo que o seu movimento é um perpétuo partir e um perpétuo retornar, mas o movimento reto é um mover-se para onde é impossível chegar, sendo a linha reta por sua natureza prolongável ao infinito, mas a circular, por necessidade, terminada e finita, ainda que os peripatéticos reputem o contrário, ou seja, que a linha e o movimento circular são infinitos, e a reta e o movimento reto, finitos e terminados. Não me digais que o centro e a circunferência são os términos das linhas retas: primeiro, porque nenhuma circunferência termina de modo que a linha reta não se possa prolongar para além da circunferência ao infinito; além disso, pôr esse centro e essa circunferência é coisa arbitrária dos homens, e é querer acomodar a arquitetura à construção, e não um fabricar conforme aos preceitos da arquitetura. Concluo, portanto, que se a Terra tem por natureza inclinação ao movimento, essa inclinação não pode ser senão ao movimento circular, deixando o movimento reto para uso das partes, não só da Terra, mas da Lua, do Sol e de todos os outros corpos integrais do universo, os quais se forem separados do todo com violência e, em conseqüência, postos em má e desordenada constituição, retornarão ao seu todo pela [linha] mais curta.

Falta vosso terceiro e último argumento; mas antes que eu o examine, quero proporcionar-vos uma certa congruência, da qual eu costumo servir-me para aqueles que, por serem de outras profissões, não se convencem com as demonstrações mais recônditas, para convencê-los com muito maior probabilidade do que se esperaria, de que é o Sol e não a Terra [560] a estar imóvel e colocado no centro das circulações celestes. Dizia então assim: nós temos oito corpos mundanos, ou seja, a Terra e os sete planetas; desses oito, sete absoluta e incontestavelmente se movem, e um só, e não mais, pode 
ser que esteja parado; e só esse é necessário que seja ou a Terra ou o Sol. Ora, procurase se de alguma conjectura muito provável se pudesse chegar à cognição de qual deles se move; e porque o movimento e o repouso são atributos principais na natureza, antes ela é por eles definida, e porque são completamente diferentes entre si, é forçoso que seja muito diferente a condição daqueles que sensivelmente se movem da condição de outro que está eternamente parado. Como, portanto, estamos em dúvida se seja a Terra, ou antes o Sol, que está imóvel (sendo certo que os outros seis se movem), quando nós por alguma forte correspondência chegássemos com segurança a qual deles, Terra ou Sol, mais se conforma com a natureza dos outros seis móveis, àquele muito razoavelmente podemos atribuir o movimento. Mas a natureza cortês nos oferece a estrada para chegar a tal cognição com dois outros atributos não menos grandes e principais daquilo que são o repouso e o movimento, e estes são a luz e as trevas, pois máxima convém que seja a diferença de natureza entre um corpo esplendidíssimo de uma luz eterna e um outro obscuríssimo e totalmente privado de luz: mas dos seis corpos indubitavelmente móveis, estamos seguros que esses são, em sua essência, privados totalmente de luz; e estamos igualmente certos que assim também é exatamente a Terra; portanto, podemos resolutamente afirmar ser grandíssima a conformidade da Terra com os outros seis planetas, e contrariamente não menor a desconformidade do Sol com relação aos mesmos. Ora, se a natureza da Terra é muito similar àquela dos corpos móveis, e muito diferente da essência do Sol, como não será enormemente mais provável (quando não exista outro que obste) que a Terra, e não o Sol, imite com o movimento os outros seis consortes? Acrescente-se a outra não menos notável congruência, que é que, no sistema copernicano, todas as estrelas fixas, corpos também esses, como o Sol, por si mesmos luminosos, estão em um repouso eterno. Essa ordenadíssima construção vem por vós desordenadamente retorcida para concluir o contrário; e deveria bastar-vos, para tirar-vos do erro e descobrir seus erros, o simples referimento. Vós dizeis assim: [561] Copérnico atribui o movimento a todas as partes lúcidas do céu, isto é, aos planetas; e ao Sol, mais luminoso que todos, nega-o, para atribuí-lo à Terra que é um corpo opaco e denso; mas a natureza, discreta em todas as suas obras, não faz essas coisas. Reordenai o argumento, Senhor Ingoli, e dizei: Copérnico atribui o repouso a todas as partes luminosas do mundo, que são as estrelas fixas e o Sol; e faz móvel todas as opacas e tenebrosas, que são os planetas e a Terra, esta também feita como eles; e assim devia fazer a natureza, discretíssima em todas as suas obras.

Isto é quanto me ocorre dizer por ora em resposta às vossas objeções físicas e astronômicas contra o sistema de Nicolau Copérnico; muito mais amplamente podereis ver tratado esse argumento, se me for concedido tempo e forças para poder conduzir a fim o meu Discurso do fluxo e refluxo do mar, o qual, tomando como hipótese os movimentos atribuídos à Terra, proporciona conseqüentemente amplo campo para examinar 
longamente tudo aquilo que foi escrito nessa matéria. Resta-me pregar de receber de bom grado estas minhas respostas; o que espero que fareis, seja pela vossa cortesia nata, seja ainda porque assim convém que seja feito pelos amantes da verdade: porque, se eu tiver com fundamento resolvido as vossas objeções, o vosso ganho não terá sido pouco, trocando coisas falsas por verdadeiras; e se, ao contrário, eu estiver errado, tanto mais claramente mostrar-se-á a doutrina dos vossos argumentos.

Setembro de 1624

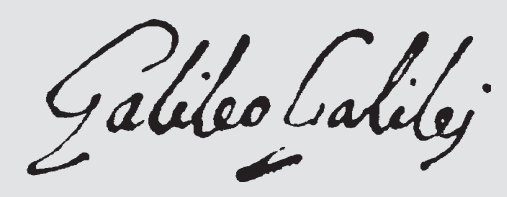

Traduzido do original em italiano por Pablo Rubén Mariconda

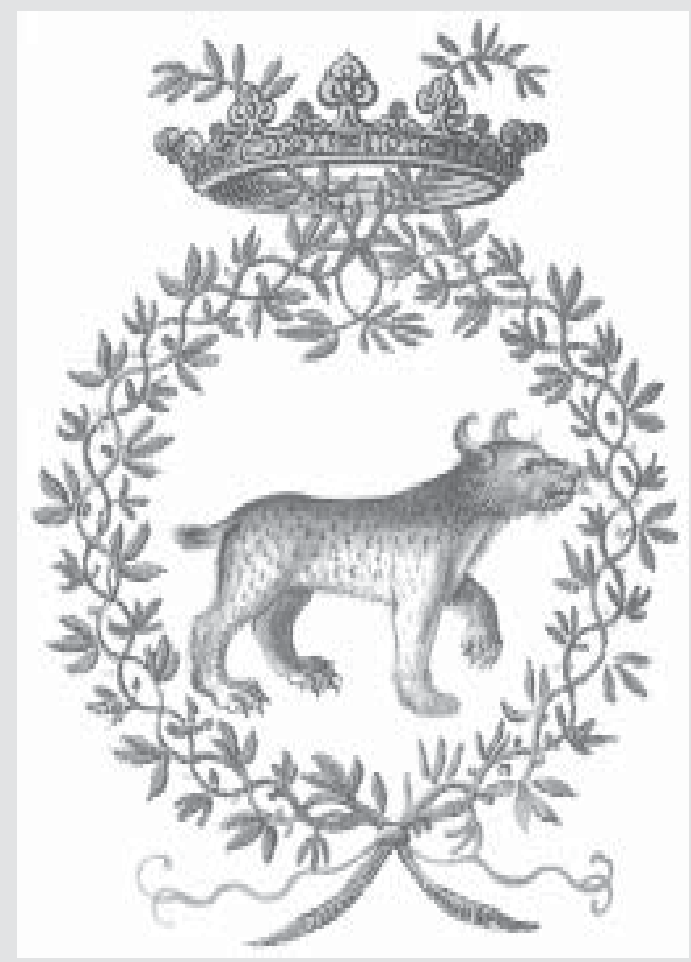




\section{Notas À Disgussão de Ingoli e À Garta de Galileu}

\section{Notas}

1 O texto aqui publicado é a primeira tradução para uma língua vernacular do original latino, intitulado De situ et quiete Terrae contra Copernici systema disputatio, que se encontra em FAvAro, A. (Ed.). Edizione nazionale delle opere di Galileo Galilei. Firenze, Barbèra Editore, 1933. v. 5, p. 397-412.

2 O termo "luminárias" era empregado para referir-se à Lua e ao Sol, porque eles brilham com uma luz mais intensa que os outros corpos celestes, iluminando a Terra.

$3 \mathrm{O}$ texto aqui publicado foi traduzido do original italiano, Lettera a Francesco Ingoli, publicado em Favaro, A. (Ed.). Edizione nazionale delle opere di Galileo Galilei. Firenze, Barbèra Editore, 1933. v. 6, p. 509-61.

4 Johannes Sacrobosco, latinização comum na época do nome inglês John Holywood. Sacrobosco é conhecido por ter escrito um tratado de introdução à astronomia, intitulado Sphera, muito difundido na época e que foi empregado mesmo por Galileu em seus cursos universitários em Pisa e Pádua.

5 "ad unguem", ou seja, "de modo preciso" ou "muito precisamente", assim como o ungüento recobre totalmente a pele. Santillana (cf. Galileu, 1953, p. 121, n. 13) afirma que a origem dessa expressão do rigor clássico é artística e pode ser encontrada no escultor Policleto.

6 Galileu parece estar fazendo referência ao Discorso delle comete (Discurso dos cometas) lido por seu discípulo Mario Guiducci na Academia Florentina em 1618 e que está na origem do debate sobre os cometas que conduzirá a Il saggiatore (O ensaiador) de 1623. Com efeito, no Discurso dos cometas, Galileu já critica diversas imprecisões científicas e matemáticas cometidas pelos defensores da cosmologia tradicional, entre as quais a primeira é aquela da relação entre o aumento do tamanho telescópico e a determinação da distância do objeto (cf. Banfi, 1979, p. 174).

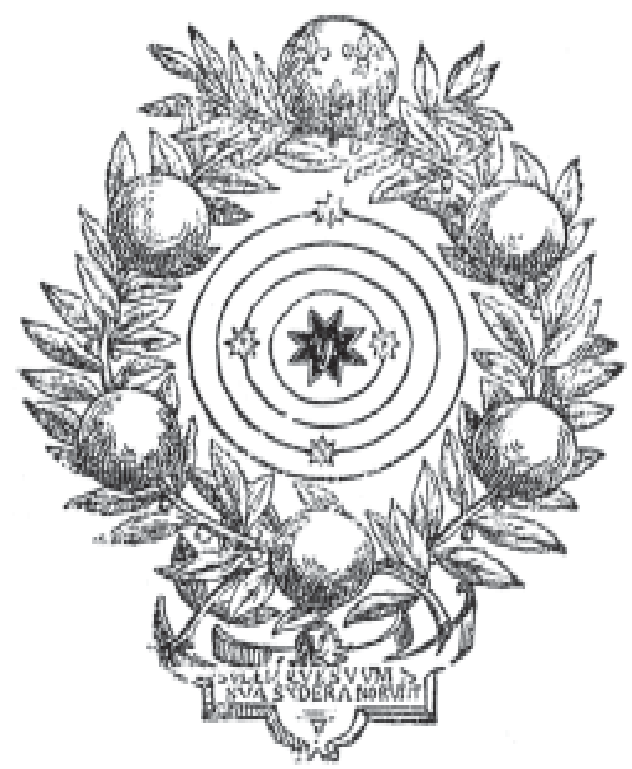

